\title{
Training and Individual Performance in Europe: Evidence from Microeconometric Studies
}

\author{
Friedhelm Pfeiffer
}

\begin{abstract}
:
Learning at school and university and also at the work place has become more important in the knowledge-based economy. This paper provides a critical review of recent econometric work on the determinants and impacts of training in Europe. Training has non negligible positive effects for firms and trainees; for the group of non trainees potential negative effects has been found in some studies. The incidence and the impact of training depend on the national education and training system. However, selectivity, individual heterogeneity, self selection, diversity of training institutions and general equilibrium effects seem to play an important role in all training systems.
\end{abstract}

Key words: education and training systems; the impact of training; self selection and individual heterogeneity; training policy in Europe.

\section{JEL-Classification: I20, I28, J24}

\section{Acknowledgement}

This research was promoted by the European Centre for the Development of Vocational Training (CEDEFOP). Sladjana Milentijevic and Jochen Möbert provided research assistance. Furthermore, I would like to thank Pascaline Descay and Manfred Tessaring for many valuable comments and remarks. The usual disclaimer applies.

Address:

Zentrum für Europäische Wirtschaftsforschung (ZEW)

P.O.Box 103443

68034 Mannheim, Germany

Tel.: $\quad+496211235150$

Fax: $\quad+496211235225$

e-mail: pfeiffer@zew.de 


\section{Introduction}

Learning at school and university and also at the workplace during working life has become more important in the knowledge-based economy. In some occupations and places of work, skill obsolescence due to technical change seems to be arriving more rapidly. This raises questions on the importance of general versus more specific types of knowledge and skills, and the relative importance of classroom-based education versus self-organised forms of learning. In European Union countries more people are better educated, more participate in continuous training and on the job learning. However, empirical knowledge on the determinants and effects of different methods of learning is still scarce, especially from a European viewpoint.

In this article the relationship between learning, training and individual performance is discussed from a theoretical and empirical point of view, based on scientific research on the determinants and impact of training in the past decade. The main question is who participates in training and for what reasons, and what the effects are with respect to productivity, wages, job search, employment, job duration, mobility, careers and other variables. These questions can be applied to all agents involved in the training process, namely for individuals, firms, training institutions as well as governments. The research task is to measure the training incidence and outcome and to look behind the mechanism which may help to explain the results. Since governments in Europe are increasingly involved in educational policies and active labour market programmes for improving the skill level of the unemployed, and public budgets are tied, evidence on the effectiveness and efficiency of such policies becomes more important.

In Europe, there is a great variety of training measures in terms of their content, duration, financing and direction, depending among other things on the changing historical and cultural role of the state in the education and training process. Thus, the determinants and outcome of training are also characterised by a considerable amount of heterogeneity. For some individuals, training has a positive impact under particular conditions, for others it seems to have no or even a negative impact. Although there is a widespread belief in a positive relationship between education, training and growth, evidence provided so far is far from complete.

In this study, attention will be restricted to a microeconometric analysis of the determinants and effects of initial and continuous training in European countries or selected regions in Europe. The goal is to quantify different factors determining training and its outcomes. It rests on theoretical and statistical models and ideally allows the testing of conflicting hypothesis or alternative explanations. Due to the increased availability of microdata and to an increased use of micro-econometric 
models in the last ten to twenty years, this is a dynamic and growing field of research. It was not possible to review all of the work done in this field. ${ }^{1}$

The report concentrates on quite recent works carried out using data from European countries. Furthermore, there is a focus on economic aspects of training, namely on incentive and investment issues. This does not mean that other aspects are irrelevant. Social and cultural aspects are also of great importance (see CEDEFOP's first report on vocational training in Europe: Tessaring 1999). However, there exists a trade-off between in-depth discussions of specific aspects of training from an economic viewpoint and a general discussion covering all aspects of training. This is not an issue for this study, since it favours a more specific discussion.

Although the main discussion centres around vocational education and training (VET), some studies also refer to higher education at universities. This is important since in labour markets different types of skills may be substitutes or complements, depending on labour market institutions and technology. Recent research on skilled biased technological change in industrial countries seems to indicate that skilled workers with higher secondary education are rather substitutes then complements with skilled workers with higher education (Machin and van Reenen 1998). In the process of technical change in particular, the share of skilled workers with secondary education is declining. Technical change seems to be biased to more cognitive and theoretical skills. The bias seems to depend not only on technological factors but also on labour market institutions. Therefore, extending the focus can help to improve the understanding of the basis for economic incentive and investment issues in education and training.

This chapter is organised as follows. The next part provides selected indicators showing the relationship between VET and economic performance in the European Union from a highly aggregated point of view using official data. Part three contains theoretical considerations on the relationship between ability, education and mobility. Individual or firm data sets are introduced in the next part, followed by a discussion of the theoretical and empirical methods underlying the empirical work and some issues with respect to the measurement of training and of outcomes. There is virtually no unified data source that has been utilised for all countries of the European Union and there is great variety in data, empirical methods and measurement of training. In part five, different results of theses studies are compared and discussed. In the last part, conclusions are drawn with respect to future research and with respect to VET policy in Europe.

\footnotetext{
${ }^{1}$ I apologise if not all available research will find itself mentioned and discussed according to its relevance. The selection of studies used for this report is the result of an electronic search strategy and a manual search in selected journals in the European Economic Review, Labour Economics, Oxford Economic Papers, The Journal of Human Resources, Journal of Economic Literature and The Journal of Labour Economics. In addition, recent research on the determinants and effects of training for German wage workers and the self-employed has been incorporated (Pfeiffer and Reize 2000).
} 


\section{VET and economic performance - selected indicators}

This part provides an overview of selected empirical relationships between the amount of education and training a person received and his/her position in the labour market. The figures presented in Table 1 are based on highly aggregated numbers for the 15 members States (EUR15, taken from EUROSTAT 1998 and the European Commission 1997) and, in the case of earnings, on 12 European members countries (taken from OECD 1998a).

In line with the discussion in CEDEFOP's first Report on Vocational Training (Tessaring 1999) VET is identified with ISCED 3 (higher secondary education) and compared to ISCED 0,1,2 (pre-primary education, primary education and lower secondary education) and ISCED 5,6,7 (higher education). The data collected refer to employment, unemployment and self-employment, to continuous training and earnings in 1995 or 1997 in the EUR15 or in 12 European countries.

It is shown in the first row of Table 1 that roughly $76 \%$ of those belonging to ISCED 3 aged 25 to 59 were employed, compared to $85 \%$ of the people belonging to ISCED 5,6,7 and $59 \%$ of the people belonging to ISCED 0,1,2. There is a monotonously positive relationship between levels of employment and the level of education, while unemployment rates are monotonously negatively correlated. Depending on the definition of unemployment, $7.3 \%$ or $8.8 \%$ of those belonging to the group ISCED 3 in EUR 15 had been unemployed in 1997, compared to $5.3 \%$ or $5.8 \%$ of those belonging to ISCED 5,6,7 and $8.4 \%$ or $12.5 \%$ of those belonging to ISCED $0,1,2{ }^{2}$

Youth unemployment rates in Europe are much higher than those for middle-aged people. However, again, there is a negative correlation between the level of education and the level of unemployment or the threat of unemployment. Those young people who have invested in an education comparable to a higher secondary education are less hit by unemployment than those who have invested less.

It is also clear from the numbers in the Table that the higher the level of education, the higher the ratio of continuous training (CT). While roughly $6 \%$ of the European medium-skilled labour force participated in CT during the last four weeks, only $3 \%$ of the low-skilled did so.

What is not as obvious and well documented is that self-employment rates (the figures in the Table are based on the group of self-employed without employees) are positively correlated with the level of skills. The positive correlation is even more pronounced for the self-employed with employees, since qualification matters even more if the self-employed recruit employees and have larger firms (Pfeiffer and Falk 1999).

\footnotetext{
2 The different numbers are the result of different definitions of unemployment. The lower numbers refer to the ILO definitions, the higher are based on the number of persons officially registered as unemployed.
} 
Education and earnings in the 12 European countries are also positively correlated. There are significant differences in the relative earnings position of VET earnings, but in every country they earn more than employed people with a lower level of education on average and less than employed people with a higher level of education. The wage distribution is more even in Scandinavian countries, but even less, for example, in Portugal, where low-skilled workers earn about $60 \%$ that of medium skilled workers and high-skilled workers earn about $183 \%$ of mediumskilled workers.

To summarise: aggregate figures for the European Union by and large show a positive correlation between investment in human capital and employment, earnings, self-employment and further investment in human capital and a negative correlation between human capital and unemployment.

There also seems to be a positive relationship between human capital, regional mobility and the use of high-tech machines at the workplace, as is reported by Pfeiffer (1997) for Germany, Entorf and Kramarz (1997) for France, or Blundell et al. (1997) for the United Kingdom. Occupational mobility on the other hand is negatively related with the amount of human capital invested in a specific occupation, since the costs of switching between occupations rise with former investments in human capital (Pfeiffer 1997).

A closer look at the individual countries reveals different numbers in all these indicators but, by and large, the same pattern can be observed. The country numbers are documented in the official reports of the European Commission and it is not necessary to repeat them in the current paper. The empirical relationship between training and the other indicators differs between the countries, with the differences being the results of many factors, among them the economic and demographic composition of the labour force, the capital and technology intensity of firms and the industry, as well as differences in the governmental framework and policies of the individual European Countries (Tessaring 1999; Müller and Shavit 1998, OECD 1998 b). 


\section{Theoretical considerations: education, innate abilities and mobility}

According to a well-known distinction, there are two types of human capital: specific and general (Becker 1964). While general human capital is valuable in the whole economy, specific human capital is valuable only in a firm, region, or in conjunction with a special technology. Since resources such as time and money are scarce, individuals, firms, training institutions and governments have to make decisions about the composition of different types of investment in human capital. Findings from the aggregate level seem to suggest that there are different solutions to the trade-off between investment in either more specific or more general VET (Levhari and Weiss 1974) depending on the pace of cultural, economic and technical progress where the individual lives.

The trade-off is a result of at least two conflicting factors. More general skills and human capital can be used in many different occupations and can help to reduce the cost of further education and learning, for example at the workplace. A large and rising degree of specialisation at the workplace, however, also requires very specific skills. People with these skills presumably start with a higher productivity entering a new workplace compared to people with more general skills. In times of more rapid technical change or increased uncertainty about the future path of economic development, investment in more general skills can nevertheless be a better strategy, because the demand for specific skills in the future is uncertain and the risk of skill obsolescence higher. In times of reduced levels of uncertainty about the path of economic and technological development, investment in more specific skills might be the superior strategy.

Larger amounts of investment in more general skills in all European countries over the past few decades can be explained as a reaction to increased levels of uncertainty about economic and technological developments. Although more people are better educated ('educational revolution'), the numbers and figures from Table 1 seem to indicate a clear hierarchical pattern in the labour market: those who are better educated are, on average, more often part of the workforce, have higher earnings, participate more frequently in training and are unemployed less often. In the past 20 years in most European countries, the percentage of workers with an academic degree has doubled (BMBF 1999). The percentage of workers with higher secondary education has also risen, but only slightly. Nevertheless, the hierarchical patterns seem to have been rather stable in recent decades. According to Mayer (1996), the hierarchical pattern has in fact been stable in Germany for the past 50 years. However, the interrelated impact of educational revolution on the one hand and skilled-biased technological change on the other, might have far reaching consequences for the future of VET, a topic which will be discussed again. 
The numbers presented in Table 1 are of a descriptive nature and are taken from aggregate statistics. The relationship must not be true any longer at individual level. A positive correlation between earnings and years of education in the aggregate is, for example, compatible with the observation that there are people with 18 years' education who do not earn more than people with only nine years education. Furthermore, it is not possible to conclude on the basis of the numbers that the observed relationships and earnings differentials are the direct result of training or VET.

First, the differences in the outcome variables such as earnings may also be the result of other factors not under investigation in Table 1, for example age, gender or occupation. Differences in the age structure of the workforce may explain part of the positive relationship between levels of education and earnings, since investment in human capital typically takes time and is therefore positively correlated with age.

Second, people may put themselves into different training routes according to their preferences and innate abilities, factors which typically are not observed very well in empirical research. People take part in training because they expect higher net benefits, which might be difficult to observe by researchers. Innate differences in abilities, for example, can explain $50 \%$ of the variance of intellectual capacities of young people in Germany (Weinert 1997, Weinert and Schneider 1998). Furthermore, the ability differentials seem to stay rather constant over long periods and might not change in schools. A statistical correlation between schooling and training variables, and outcome variables such as earnings, might therefore be biased due to omitted variables such as innate abilities or ambitions, i.e. due to selfselection. The bias can be in both directions.

In economic terms this is part of the human-capital versus signalling debate (Cohn and Geske 1990 Tessaring 1999, Weiss 1995, Wolpin 1977). The positive correlation between higher earnings and level of education may not be the result of investment in human capital, but higher investment in human capital might just be a signal of higher innate abilities. 'In the most extreme form of this screening hypothesis, schooling serves only to identify those individuals who are more productive in the market, the proposition being that an individual's productivity is unaffected by the formal schooling process.' (Wolpin 1977:950).

This debate is also relevant for CT, although the incentive and investment character of decisions in CT differ. Firms already know their workers and the information problem has therefore been solved and can no longer be the central issue if we look at firm and work-related training. However, training and promotion schemes are highly interrelated (Prendergast 1993) and the causal relevance of training for promotion can be questioned. Training at the workplace might rather be a consequence of promotion than promotion being a consequence of training. In that 
case, research on the determinants of promotion becomes as important as research on the determinants of training.

For the purpose of this study, training is defined as an investment by individuals, firms or the government. While the costs of training have to be born today, benefits will manifest themselves in the future. The outcome of training is uncertain to different degrees of depending, for example, on the quality of the training institution, the path of technical change and economic growth, but also on the size of cohorts and demographic change (Tessaring 1999).

Investment in training is not the only relevant decision for any involved party, namely individuals, firms or governments. Firms, for example, have to decide on products, product quality, capital investment and innovations. Some of these decisions are highly interrelated to the training decisions, such as introducing new products or new processes for improving the firm's position in the market. Firms have the option to hire skilled labour without training, which might lead to negative external poaching (Hocquet 2000) and insufficient training in a private economy.

The term 'training' should not be restricted to formal training activities, especially when one looks at CT (Weiss 1994, Pfeiffer and Reize 2000). Learning by doing, that is informal training at the work place, has important economic implications as well. Arrow (1962) assumes that the productivity of a firm depends on the total experience of all firms (measured by accumulated gross capital investment). In the course of time the same output will then be produced with less and less labour ("learning curve"). The productivity-effect arises solely from the process of learning through production ("learning-by-doing"), and the common knowledge character of experience ("knowledge spillovers").

Individuals have to choose between several alternatives and actions. They can choose to change the firm in order to get higher wages, for example, or they can chose to participate in privately financed training programmes. For individuals, to undergo VET is an important and far-reaching decision and they should therefore be careful when making this decision. Expectations about the outcome of training, taking into account the fact that other people may also decide to train, do indeed play a measurable role for individual behaviour (Heckman, Lochner and Taber 1999).

One general aspect to consider for all parties is the topic of timing of investments in human capital. Among other things, timing depends on compulsory school regulation, individual abilities, labour market regulations and career plans. This consideration suggests that the decision to undergo a particular training measure is part of a larger set of economic activities of firms, training institutions and individuals. Therefore, it does not always make sense to talk about the effect of training isolated from their context, since training is one of several simultaneous economic activities. 
The determinants and effects of training depend on labour market institutions and the path of economic and technological development. They also depend on national education and training systems. That is, they depend on how and by whom education and training is financed, on its content, qualification and assessment. Training systems in Europe vary to a great extent with respect to all of these factors, as has been documented in the first report on vocational training. Comparing outcomes of different training types in the different systems in Europe may help to understand the complex interrelationships between education, training and outcomes. It may also provide a guideline for the optimal spacing of investment in training throughout life and improve the understanding of the role of government in optimising content, finance, assessment, qualification and participation.

Since training is viewed as an investment in this study, there should be a parallel between the cost and the benefits of training (Lynch 1994, Booth and Snower 1996). According to the distinction of Becker, the individuals receive a large part of the return of investment in general skills and human capital themselves. They should therefore bear a large part of the costs. This system works if, after finishing the investment, individual productivity is higher and wages on average are higher for the trainees thus providing an incentive for the investment. Furthermore, this system only works if individuals can borrow money to finance their general training or if wages are lower during the training period. If capital markets are not perfect, that is, if there are credit constraints, not all the people who would like to participate in training for reasons of efficiency might be able to do so. This can be an important issue for privately founded education systems and usually serves as one rationale for government interventions; another rationale is positive externalities of education, because they may also lead to insufficient investment in human capital in a free market economy (Booth and Snower 1996). If government subsidises general training, private returns in the form of higher wages can, in principle, be lower than in the case of training which is purely privately financed.

Changes in wages are not only determined by training, but also by a larger set of factors (Hamermesh 1993), among them the amount of investment in machines and human capital investments in the population. If the amount of training in the population is considerable, which is the case in all European countries, it is necessary to take general equilibrium effects of training into account. The returns to training can differ depending on whether one looks from a partial or general equilibrium view (Heckman and Lochner 1998). In a general equilibrium view, the cost of training and the longer term impact on the economy-wide wage structure should be taken into consideration.

The benefits of more specific types of training may lie in higher productivity gains for firms. Therefore, firms should bear the costs of more specific training and wages may not change after training. The relationship between the optimal amount of investment in general and specific human capital depends among other things on individual preferences and abilities, the capital and technology intensity of firms and 
costs and financing arrangements. The returns on more specific human capital may additionally depend on the amount of general human capital that a person has acquired. Thus, education, initial and continuous training are interrelated and the incidence and impact of training depends on the training system of a society as a whole.

Over-education or coordination failure between several types of training may arise in an economy. An example of co-ordination failure seems to be the German training system, where general university education is largely paid for by the government, while vocational training is not. Recent trends in the demand for labour suggest that due to rapid technological change, vocational skills are becoming obsolete at an increasingly faster rate, which favours cognitive and more academic skills (skill biased technical change, see Blechinger and Pfeiffer 1999, Machin 1996, Machin and van Reenen 1998). The bias in favour of skilled labour depends furthermore on labour market institutions. The more rigid the wage structure is, the faster upskilling will be during the computer revolution (Blechinger et al. 1997).

Labour markets in Spain might serve as another example of situations where labour market regulations also have secondary undesired effects. One reason for the very high unemployment rates for young people in Spain are the employment protection rules for older workers. The Spain youth labour market has therefore been characterised as a high-skilled - bad job labour market, since high skilled individuals end up in low skilled jobs, crowding out low skilled individuals (Dolado et al. 1999).

For other authors, the problem of under investment in general skills might be a serious problem for economic development. There might be a complementarity between general human capital and technological development (Acemoglu 1996). A lack of basic skills might hamper the speed of innovation. Firms who want to innovate have to train their workforce, which means additional costs of innovation for the firms and therefore less innovation and productivity gains. This can theoretically lead to the vicious circle of "bad skills - bad jobs" or "low innovation low training" equilibria (Snower 1996).

Individuals, firms, educational arrangements and labour and product markets are characterised by a large degree of heterogeneity, where VET and CT play different roles. The rest of the paper is devoted to looking more closely into the relationship between VET, CT and outcomes in the labour market using data sets from firms and individuals. The following part introduces the potentials and limitations of the data sets, the methods used, as well as measurement problems with the training variables and the main explanatory variables. 


\section{Econometric methods, data and measurement issues}

\subsection{Econometric methods}

Most studies reviewed below use econometric methods to quantify the determinants of training and its impact on wages, hours of work, duration of job search, duration of employment and other outcomes. Most of the studies explicitly take care of the self-selection problem in quantifying the impact of training. They model the decision to train and the outcome of training simultaneously.

The problem of impact measurements in social sciences ${ }^{3}$ when compared with natural sciences is that social programmes cannot be easily isolated from real life processes (with the exception of psychological experiments). Social programmes such as public VET policy are embedded in real life. The main task of research is to measure the impact of the programme despite the fact that many other factors simultaneously influence the participating individuals or firms and thus the desired outcomes. These influences stem from individual, social, economic and policy factors.

The coefficients of econometric works based on single equation outcome models with some training indicators as an explanatory variable can be seriously biased by self - and/or programme - selection. Participants in training do not usually constitute a random sample of the workforce or the population of unemployed people. Those who see comparative advantages and higher net benefits in training might have higher probabilities of participation. Comparative advantages may result from lower costs of training or higher expected returns, or there might be special preferences towards training.

There is an ongoing scientific debate on the question of selectivity, individual heterogeneity and the role of institutions. If selectivity is empirically relevant, then simple comparisons of means of outcome variables between non-participants and participants in training and the coefficients of single equation models might be seriously biased. More complex econometric models would often be needed to solve the so-called 'comparison problem'. It is not possible to observe the outcome of an individual participating in training and the outcome of the same individual in the case where he/she would not have participated in that training. On the other hand, the difference between the mean earnings of non-participants and participants in

${ }^{3}$ For an in depth discussion of the methodological issues see Heckman, LaLonde and Smith (1999) and for a broader discussion of an evaluation of the welfare state and cost-benefits analysis of education and tax policies, Heckman and Smith (1998) and Heckman, Lochner and Taber (1999). Discussion in the paper will concentrate on the determinants and effects of training with the exemption of training programmes as part of the active labour market policies for the unemployed. For an extensive literature survey on impacts of active labour market programmes in the United States and Europe, see Heckman, LaLonde and Smith (1999). 
training can be a misleading guide for assessing the impact of training. This is the case, for example, when participants in training programmes are more highly motivated or have higher innate abilities than non-participants. In such cases the earnings, working hours, or other outcome variables of interest may have already been higher before the participation in training and training may have no impact at all.

The advantages of training are usually identified by the difference between the two outcomes, one observed, and the other not observable. To assess the impact of training, one has to rely on estimates which can be based on a group of people without training. Obviously this group of people should be identical with the people participating in training with respect to all relevant characteristics (whether they are observed or not) of the people and the environment in which they live. The comparison problem is to find such a control group. The precision and accuracy of the estimate will depend on the precision and accuracy of the control group. While some researchers believe that the comparison problem can only be resolved by means of social experiments, others have developed statistical and econometric tools for unbiased estimates of the impact of training with the help of non-experimental data.

In classical experiments, prospective programme participants have been randomly divided into one experimental and one control group. Given this research design, the difference between the outcome in both groups must be a result of the programme if all other conditions are similar. The other approach uses information from participants and non-participants of actual programmes. In this case, the individuals participating in a programme have been selected systematically, either by themselves or by specific programme rules. Since social experiments are rare in Europe, current research into the determinants and impact of training in Europe depends on non-experimental data and adequate econometric tools.

One possible solution is the comparison of the individual outcome variable before and after participation in VET in the framework of an econometric model (see Blundell et al. 1997, Pannenberg 1997 and Pischke 1996 for such a procedure). This information is, however, often not available, for example when people are young and have no labour market experience before entering VET. Pfeiffer and Reize (2000) use the concept of the comparison group in two ways. On the one hand they compare trainees and non-trainees, taking care of the selection problem with econometric methods. This is a common way of taking advantage of nonexperimental comparison groups.

Furthermore, the determinants and impacts of continuous work-related training between wage workers and the self-employed are compared. In this case, the selfemployed group serves as a comparison group for assessing the relevance of estimated effects of CT for the group of wage workers. The self-employed decide for themselves concerning the amount of investment in training. In the case of wage workers, firms decide who participate in their work-related training programmes. 
The decision process is therefore more complex for wage workers, and aspects such as poaching externalities, funding or promotion ladders become important. Therefore, the estimated impact of training in the self-employed group provides a sort of bench-mark value for assessing the role of human-capital for training in the group of wage workers (see Cohn and Geske 1990 for a survey on former studies based on differences between self-employment and wage work).

There might be intentional and unintentional outcomes of training, or the lack of it, which are either favourable or unfavourable for the individual, the firm, region or industry, or the whole economy. Most econometric studies investigating training analyse the direct intended impact at the personal or company level for some favourable variables such as wages, productivity, employment prospects, etc.. Secondary, sometimes undesirable effects occurring to other individuals, or at other firms or industries, might be important (so-called general equilibrium effects), although they are seldom investigated in empirical research. Examples of research which addresses these issues in a more indirect manner are the aforementioned studies on skilled-biased technological change and on over-education (Hartog 1999).

Secondary effects cannot be excluded empirically a priori. If some firms for example provide excellent training for their employees and thus are more competitive, other firms might lose market share, or their employees may have a higher probability of being dismissed. Such negative indirect effects are, however, difficult to trace, and their assessment often requires costly research designs. One important general equilibrium effect stems from the fact that government promotion of VET has to be financed and therefore affects the budgets and the welfare of taxpayers.

\subsection{Microdata on VET}

The aim of microeconometric studies on education and training is to investigate the determinants of training and assess its impact on subsequent working careers taking into account observed factors such as age, gender, labour market conditions as well as unobserved factors such as motivation or innate abilities. These studies are based on microdata. The units of observation are either individuals, firms or both. ${ }^{4}$ The aim and scope of the data differs considerably. Not all were, for example, collected for studying VET-related issues exclusively. This part provides an introduction to the empirical basis, which should be helpful for a critical understanding of the results. The data belong to one of the following four types (see Table 2):

- cohort data (CD);

- cross sections (CS);

- repeated cross sections (RCS);

- panel data (PD).

\footnotetext{
${ }^{4}$ There is a tendency in empirical work to use matched employees-employer data (see Bellmann et al. 1999, Bratberg and Nilsen 1998, Entorf and Kramarz 1997, Krueger and Rouse 1994).
} 
(table 2)

CD consists of all persons or a sample of persons born for example in 1958 in England. These persons are either interviewed once in a retro perspective manner which is the case with the German Life History Study (GLHS), the Brabant Survey (BRAS), the Norway Survey (NORS) and the Lancashire Career Data Survey (LCSD), or are followed during their life on a regular basis. An example for the latter is the English National Child Development Study (NCDS).

The four cross section data (CS) survey samples of persons or firms from a welldefined population at a point in time. The Dutch wave of the International Adult Literary Survey (DIALS) is a survey based on a sample of the whole Dutch population in 1995; the French Survey on Education and Qualifications (FDQ) is based on a sample of the adult French population; the Company Training in Ireland (CTIRE) data survey firms from Ireland in 1993, and the Community Innovation Survey (CIS) surveys firms from manufacturing in 12 European countries in 1993.

If survey data for well-defined populations are produced regularly without being connected individually, they are called repeated cross sections (RCS). Examples of this type of data are the German Qualification and Career (Q\&C) data, a representative sample of employees surveyed in 1979, 1985 and 1991; the German Labour Force Survey (GLFS), a representative sample of the population surveyed every year (since 1991 GLFS has been part of the European Labour Force Survey), and the Swedish Level of Living Survey (SLLS), a representative sample of the Swedish population surveyed 1968, 1974, 1981 and 1991.

The last type of data sets is termed panel data (PD). Here, the same units of observations are surveyed at different time points again and again. Six studies rely on panel data, three on individual panel data (Dutch Biannual Labour Supply (OSA), biannually since 1992; German Socio-Economic Panel (GSOEP), annually since 1984; Norwegian social insurance data (KIRUT) since 1989), three on firm panel data (Collective Bargaining in Large Firms (NCGE) in Spain since 1979, the Hannover Firm Panel (HFS) covering industrial firms in Lower Saxony, Germany since 1993 and the German Plant Panel (GPP) data covering plants in Germany since 1993).

In the recent Employment Outlook (OECD, June 1999), the determinants and wage impacts of continuous training in seven OECD countries are studied: Australia, Canada, France, Germany, Great Britain, Italy, Netherlands also based on microdata. For European countries, they used the 1993 cross section of the German SocioEconomic Panel, the French Survey on Education and Qualifications from 1993, the 1996 cross section of the British Household Panel from 1996, the 1991 Bank of Italy survey and the 1994 cross section of the Socio-Economic Panel from the Netherlands. For a description of the last three data sets, which look quite promising for microeconometric research on training issues and which are not mentioned in Table 2, see OECD (1999). 
The remaining data designs differ according to the main focus of the surveys (see Table 2). While some aim directly at analysing training issues, others have different aims or should best be characterised by a multitude of aims. Nevertheless, these data have been used for analysing the determinants and impact of training. It is necessary to keep the main focus of the data sets in mind when interpreting the results or discussing policy implications.

The following categories of aims can be distinguished (see also Table 2):

A: the main objectives are the study of the determinants and the impact of education and training (CTIRE, GLHS, FDQ, LCSD, Q\&C);

B: the main objectives are also related to education and training (BRAS, DIALS, GSOEP, GLFS, NCDS, NORS, OSA, SLLS);

$\mathrm{C}$ : the objectives focus on a different set of topics; meaningful questions on education and training are included (CIS, GPP, HFP, KIRUT NCGE).

From the 18 data sets under consideration, five belong to category A, which was originally designed to provide an understanding of the relationship between training and the outcome of training, for example the performance of the labour market. Eight belong to the second group, where the study of training is one among several aims. As an example, the German or European Labour Force Surveys should be mentioned, which aim at investigating issues such as participation, family situation, unemployment, social insurance and so on, and continuous training also. Five sets of data belong to the last category. They provide meaningful information on training, but have different aims. An example for this category is the "Collective Bargaining in Large Firms" (NCGE) study from Spain, which aims at investigating wage-setting in large Spanish firms, but nevertheless provides meaningful information on firms' investment in training.

The types of data have specific advantages and disadvantages for investigating VET-related themes. Below, some of them will be sketched very briefly. Cohort data provide valuable information for a well-defined cohort of persons, but no information on individuals of other cohorts. Interactions between cohorts on the labour market cannot be studied. With cross section data it is on the other hand not possible to disentangle age and cohort effects. Earnings equations based on cross sections presuppose constant age-education-earnings relationships over time, which might be questionable in a dynamic world.

Longitudinal studies based on panel data or repeated cross sections are constructed to overcome these restrictions. Aspects of individual biographies, such as lifetimeearnings-profiles or education and training histories can, in principle, be investigated if the time period is long enough. The GSOEP, for example, started in 1984 and contains a biographical annex for all persons surveyed for the first time in 1984. In principle longer life histories can be reconstructed with such a design. 
However, longitudinal data might be plagued by the problem of comparison of variables and other information over time and might be affected by fluctuations in the business cycle or political and other events. Changes in the definitions of earnings, working conditions and hierarchies over longer time periods might lead to spurious correlations in empirical work.

The lessons to be learned from empirical work seem to be that there is no single ideal data set for all research problems. An ideal data set will depend on the goal under investigation and on financial resources as well, since conducting surveys is expensive.

Recently, in the OECD countries and/or the European countries, four surveys have been conducted to provide harmonised training statistics for OECD or European countries (OECD 1999): the International Adult Literacy Survey (IALS) 1994-1995, the European Labour Force Survey (ELFS) 1997, the OECD/INES (Indicators of Education Systems) data on continuing training 1991-96, and Eurostat's Continuing Vocational Training Survey (CVTS) 1994. These surveys provide valuable insights into training among the different countries. Comparative research on VET in different countries based on cross section data now becomes possible.

However, measured participation rates in $\mathrm{CT}$ differ significantly between the four surveys (OECD 1999:142, 144), which is presumably a result of different definitions of training between the surveys and, furthermore, of sample sizes. To give the reader a numerical example of the diverging participation rates in career or job-related training: in Germany this rate amounts to $20 \%$ according to the IALS, $4.2 \%$ according to the ELFS, $33.3 \%$ according to the OECD/INES, and $24 \%$ according to the CVTS (OECD 1999: Table 3.2). That seems to indicate that harmonisation of surveys to provide harmonised statistics might not always be a superior strategy of data collection.

Some of these surveys have been used for micro-econometric work in some countries. The IALS data have been used for investigating training in the Netherlands (Oosterbeek 1998), the ELFS data for investigating training in Germany (Pfeiffer 1997). Although these surveys seem to have specific problems as mentioned above, VET-related research could be improved if the data were to be used more systematically for all countries.

\subsection{The measurement of training and outcomes}

Training, like human capital, has several dimensions. In empirical research it is necessary to measure the dimension of training. There are qualitative and quantitative dimensions. The following dimensions have been investigated, some of them overlapping (see Table 3). Besides more qualitative dimensions such as training in a classroom, at or outside the workplace, or training with or without a qualification certificate, there are some quantitative dimensions, such as the hours, days or years of training, or the cost of training. The studies presented all use 
slightly different definitions of training and none include comprehensive information on all dimensions of training.

(table 3)

Furthermore, it is necessary to measure the impact of training, which may reveal further dimensions (see Table 4). There must be a close relationship between the aim of a training programme and the measurement of outcome variables. In empirical literature, outcome measures include wages, earnings, productivity, hours of work, time of search for the first job after VET, length of duration of the first job, mobility (regional, occupational), upward mobility, employment and unemployment probabilities, further training and others.

(table 4)

While some types of vocational training aim explicitly at providing more general skills in the sense of transferable knowledge (transferable between firms, technologies and over time) such as the German dual vocational training system, others aim at providing rather specialised skills (such as large parts of CT) to master specific aspects of everyday work, for example a two day training course to understand a new version of an internet browser. Then there are even more different types of training which aim at reintegrating people into the regular labour market, which applies for most active labour market programmes.

Furthermore, training programmes might have undesired secondary effects. This leads to a distinction between the direct impact of training at the individual or firm level and indirect impact, sometimes termed 'general equilibrium impact'. For example: if an increasing number of people are trained with specific skills, the returns to this type of training may decline, or the number of people trained with more general skills may have an impact on the demand for labour in a different skill group.

\subsection{The set of explaining factors}

The task of the research is to assess the determinants and the isolated impacts of VET. Researchers try to quantify the direct impact of training, which is the difference between the outcome variable before and after training within the framework of econometric models. Often the determinants of participation in VET and its outcomes are modelled simultaneously, which seems a natural way of tackling the issue, since training is chosen individually or by firms through its impact on desirable outcomes. The set of explanatory factors explaining training usually includes all or some of the following categories of variables:

- Socio-demographic background and work history (age, gender, experience, periods of unemployment, ...);

- family background information (education of parents, place of living, ....); 
- educational background and ability variables (intelligence scores, educational degrees, ...);

- information on former or current labour market conditions (regional unemployment rate, ...) and characteristics of the firm (if training was or is provided at a firm);

- information on the training institution (type of school, qualifications,...).

The set of explanatory factors explaining the impact of training includes variables which also belong to the above categories of variables and also training indicators.

\section{Discussion of results}

\subsection{Summary}

The determinants and effects of training depend on individual characteristics, labour market institutions and the path of economic and technological development. Furthermore, they depend on national education and training systems. Education and initial and continuous training are interrelated, and the incidence and impact of training depends on the training system of a society as a whole.

Critical review of empirical literature seems to indicate that the more structured the whole VET system is through institutional arrangements and state regulation, and the higher the amount of more general investment in human capital that provided in the early years of life or of an employment relationship is, the lower the measured returns to continuous training are after the high initial investment. Conversely, the less structured the training system is, the higher the measured returns of continuous training seem to be.

Furthermore, selectivity plays an important, but different role in training systems. It seems as if the more people or workers are trained to reach a higher level of general vocational skills, for example through State-financed training systems, the greater impact selectivity has on the labour market after finishing VET at schools and/or firms. The role of CT then changes: worker promotion becomes more important and those who are promoted are trained as well. However, if the government-regulated training system provides less general human capital during the early stages of an individual's life, selection for training at the workplace becomes important and the aim of training lies in providing specific or general skills.

\subsection{The determinants of training}

The discussion of results starts with the question of who participates in VET and CT? While in some countries, for example Germany, the difference between initial VET and CT is rather clear cut, in other countries such as the United Kingdom, the difference is not so clear. In Germany, young people who do not enter the university system have to participate in the dual vocational training system. Young people either start a regular two-and-a-half to three-and-a-half year apprenticeship training 
scheme with a firm, or if they do not find an apprenticeship training place, they have to go to special VET schools until the age of 18. After finishing that phase of education and training, continuous training can start. In the United Kingdom statutory schooling ends at the age of sixteen. Thereafter there are three main qualification pathways (job-specific training, general vocational education, general education, OECD 1998b, Chapter five). One difference to the German system seems to be a higher degree of freedom and less institutional regulations with respect to the choices of individuals and firms. Therefore, the boundaries between initial and continuous training are sometimes less obvious.

Evidence from empirical work (which have been put together in Table 5) can be summarised as follows:

- Family background, school quality and ability (measured for example with mathematics scores) are important determinants of participation in VET and CT;

- CT first increases in parallel with experience and begins to decrease after 10 to 20 years;

- Higher educational qualifications or vocational skills seem to increase the probability of receiving $\mathrm{CT}$; there seems to be a correlation between the occupation chosen in initial and further training;

- Former participation in CT also seems to raise the probability of CT;

- Women do not have higher probabilities of participation than men and in some studies probabilities are lower;

- Self-employed persons have a lower probability of participation than employed workers;

- Minority groups, for example immigrants, have a lower probability of receiving training;

- Part-time workers receive less training than full-time workers;

- Larger firms provide more training than smaller firms;

- Training probabilities in growing industries and in high-tech industries are higher;

- Training probabilities are higher in more unionised industries and union members receive more training than non-union members;

- The probability of training decreases with job tenure, although the pattern in the first 20 years is far from being monotonous; workers staying in the firm where they received initial training have a lower probability of training than other workers;

- Public sector establishments provide more training than private sector establishments; 
- for the self-employed, non-formal CT seems to be more important than formal $\mathrm{CT}$;

- Initial training and CT seem to be substitutes in part.

(table 5)

These results indicate that selection and selectivity are indeed important issues in the determinants of training. Training does not seem to be a random element of human economic activity. However, not all the results shown in the list are found in all of the studies. It is these differences that can help to obtain a deeper understanding of the forces underlying training. The following issues are discussed in greater detail: the relationship between initial and continuous training, the role of gender and the determinants of initial training.

Although there is some need for more differentiation, most of the studies seem to confirm the positive relationship between the amount of human capital received in initial education and training and continuous training which becomes clear from the aggregate data (see Table 1) in a multivariate statistical framework. For studies based on personal data, see Arulampalam and Booth (1997), Blundell et al.(1997, 1999), Goux and Maurin (1998), Groot (1995), Pannenberg (1995, 1997, 1998), Schömann and Becker (1995) and OECD (1999); for studies based on firm data, see Alba-Ramirez (1994), Gerlach and Jirjahn (1998).

Oosterbeek (1998), who examined supply and demand factors in terms of the training determinants, was able to show that while for firms (the demand side) education is insignificant, it is not for individuals. He suggests that the positive correlation between education and CT found in most of the studies is the result of omitted ability variables or self-selection. Furthermore, he argues that this finding is not a result of selectivity effects from the demand side. For firms it does not matter whether they train better educated or less educated workers, but for individuals there are differences in the payoff of training, with a higher payoff for the better educated. Therefore, more better educated people are more likely to participate in training.

Pfeiffer and Brade (1995), who processed detailed information on the subject of university education (engineers, natural scientists, employees in administration, economists and others), find that there is no monotonous positive correlation between education and CT. Their findings suggest that workers with a university degree in engineering or natural sciences indeed have no higher probability of participating in CT than workers with apprenticeship training. Conversely, teachers and other workers with a degree in social sciences had a much higher probability of participating in CT. The authors conclude that in the age of natural science, engineers and natural scientists are the main producers of new knowledge and new products, and that the activity of this group of workers generates the need of CT for other staff. Therefore, engineers do not have the highest probability of participating in $\mathrm{CT}$. 
Findings suggest that education is not the only factor of the positive relationship between initial and further training. The activities of an employee, that is his or her position and tasks within the firm, have some explanatory power, too. Most of the studies cited only give some broad information on education and are therefore not suited as a basis for a deeper discussion of this question. One further exception is the study of Pfeiffer and Reize (2000) which indicates that in Germany the determinants of training for workers with an apprenticeship degree are higher if the type of apprenticeship belongs to the electro-technology or commerce industries compared to other trades. Such differences point to occupation-specific differences in skill needs resulting from technological change, or in differences in the quality of initial training in different trades.

A comparison between employed and self-employed people in order to identify the determinants of self-employment indicates that for the self-employed, the negative gender effects are not significant (Pfeiffer and Reize 2000). Since the self-employed decide on CT on their own, this says something about the role of the worker-firm relationship in the selection of participation in CT. It is not that women do not want to undergo training, but that firms seem to prefer men. A similar finding and argument is reported by Oosterbeek (1998), who argues that this behaviour may be the result of a higher investment risk, since women have a higher probability of career interruptions than men. The OECD (1999) study also found no significant gender differences in the participation rates based on recent surveys.

Focusing now on the determinants of participation in initial VET, the evidence suggests that school quality and innate abilities have some explanatory power. The family background (parents' educational attainment) and the alternatives available to the individual also seem to be important for explaining participation in VET. There is by and large a positive relationship between parents' educational qualifications and the educational qualifications of children, although during the educational revolution a larger number of children from parents with lower educational qualifications entered universities (for Germany see Pfeiffer 1997). Innate differences in abilities can explain $50 \%$ of the variance of intellectual capacities of young people (Weinert 1997). Furthermore, the ability differentials stay rather constant over long periods and seem to be unaffected by schooling.

The study of Andrews and Bradley (1997) gives insights for a region in Britain. The results seem to indicate that a higher academic level reduces the probability of participating in VET after compulsory school and increases the probability of attending a university. The same is true for young people's occupational preferences and the associated expected lifetime earnings. Judging from that variable, nonvocational continuing education is preferred to continuing vocational training, which again is preferred to the rest of alternatives (youth training schemes, working and on-the-job training, unemployment).

School type and quality seem to matter, although this is an ongoing debate. Dearden, Ferri and Meghir (1997) provide a summary of the research on school quality, 
educational attainment and wages, a large part of which has been carried out in the USA. Andrews and Bradley (1997: 399), for example, differentiate between standard schools maintained by local authorities, a "voluntary/grant" category and "special" schools, "which cater mainly for the needs of young people with learning difficulties".

These variables have some explanatory power for explaining the long-term career choices of pupils. For example, school leavers from special schools have a higher probability of joining youth training schemes, while those from the first category have a higher probability of joining non-vocational continuing education. School size can also have an influence on the probability of non-vocational continuing education, where the greater the school size, the greater the negative influence.

Andrews and Bradley (1997: 408) conclude: "Moreover, the estimates ... suggest a clear ranking of outcomes, where the most able end up following non-vocational continuing education, and the least able end up either unemployed or with jobs with only on-the-job training...." It is not clear how valid this statement is for different countries in Europe and for different types of training systems.

\subsection{The effects of training}

Does training have a positive impact, for example on productivity, job search duration and mobility and if so, what is its quantitative magnitude? Which part of the observed differences in wages or wage growth, in hours of work, or job duration can be attributed to training? Most econometric studies have investigated the effects on wages, on earnings or corporate productivity.

One should bear in mind that in standard earnings equations (so-called Mincer earnings equations) in cross-sections, 25 to $50 \%$ of the variance of earnings or wages can be explained by human capital variables such as years of education or educational qualification, training, age, professional experience, occupational status, technology and gender. The rest remains unexplained. This demonstrates that a quite substantial part of earnings variation among workers remains unexplained by the standard human capital approach. Other studies investigate the effect of training on job search duration, length of job duration, hours of work, post training firm job mobility and upward mobility, and the impact on employment probability. Although training and other human capital variables often have some explanatory power, again a large part of the individual variations in these outcomes variables remains unexplained by empirical research.

The findings of the econometric studies, which have been put together in Table 6 , can be summarised as follows:

- there is a positive correlation between VET and wages (found in all studies with the exception of one study for Norway, where the effect is zero, Elias et al. 1994; in the other Norwegian study, the coefficient is positive, Bratberg and Nilsen 1998); the positive relationship between VET and wages depends on the type of 
VET, the country and the group of individuals under investigation; the estimated returns range between 0 and $40 \%$;

- family background and ability have measurable effects on earnings (Blundell et al.1997, 1999);

- the estimated returns to training are by and large positive for the group of participants; there are examples where the estimated returns turned out to be negative for the group of non-participants (Groot 1995, Groot et al. 1994, Oosterbeek 1998). This suggests the existence of comparative advantages, general equilibrium effects and self selection;

- there is evidence that the returns for employed workers are higher than those for the self-employed (Pfeiffer and Reize 2000);

- there is evidence that the returns to CT are higher if they are financed by individuals instead of firms (Pannenberg 1997);

- there is evidence that informal CT has returns (Weiss 1994) as well and that these returns are lower than those of formal CT (Pfeiffer and Reize 2000); there is further evidence that the degree of formalisation matters (Pfeiffer and Reize 2000), as well as school quality (Dearden et al.1997, not cited in Table 6);

- there is evidence that the returns from CT depend on the educational qualification and on gender (Blanchflower and Lynch 1994, Blundell et al. 1997, Elias et al. 1994 and OECD 1999, not cited in Table 6); the evidence for gender seems to be mixed, as well as the evidence with respect to educational qualification (Jonker et al. 1997); while former studies sometimes found a negative relationship between educational qualification and returns to $\mathrm{CT}$, new studies with different econometric methods seem to challenge these findings (Abadie et al. 1999, not cited in Table 6);

- there is evidence that hours of work are positively correlated with CT (Pfeiffer and Brade 1995);

- there is evidence that upward mobility rises parallel to CT and educational qualification (Schröder and Blomskog 1997, Goux and Maurin 1998, Pannenberg 1997);

- there is evidence that the employment prospects increase with educational qualification and firm-related CT (Blundell et al. 1997, Bratberg and Nilsen 1998, Mayer 1996, Mayer and Carroll 1987);

- there is evidence that job search duration after initial education and the length of job spells in the first job rise with educational qualification (Bratberg and Nilsen 1998) and with the amount of human capital the firm invested in apprentices (Franz and Zimmermann 1999, not cited in Table 6); 
- productivity of firms rises parallel to training (Alba-Ramirez 1994, Gerlach and Jirjahn 1998);

- there is evidence which suggests the existence of poaching externalities (Hocquet 1999);

- there is evidence that firms not only gain from specific investment in human capital (specialised training), but also from more general investment in human capital (general training) (Barnett and O'Connell 1998).

(table 6)

Although considerable methodological and data problems remain to be solved - the result stems from different countries, different data, estimators and methods used, and often the main objective of these studies is rather positive than normative analyses -these are interesting results which are especially important for VET policy.

First, results indicate that classroom education, work-related and more general types of training are beneficial for both firms and individuals. These benefits are not negligible and are sometimes rather large. Benefits from education. learning and training seem to occur to a great extent between individuals, firms and regions. Individual heterogeneity, differences in the education and training systems, are important factors behind these differences.

Second, the result that education and training has positive benefits does not mean that policy has been optimal or that publicly provided VET should be enhanced. There is rather a lot of evidence for positive impacts of VET on participants and comparably less evidence on the impacts of VET in the group of non-participants. In fact, there is evidence that self-selection on the one hand and general equilibrium effects on the other are at work. Training has positive effects and net benefits for the group of trainees. However, there is also some evidence that for non-trainees, net benefits might not in fact be positive. From the viewpoint of economic efficiency for these individuals, training might be a bad investment for firms, individuals and society. Furthermore, most of the studies reviewed do not investigate the costs of VET.

Third, any benefits of CT seem to decrease with the level of educational qualification. The lower the amount of initial training, the lower the incidence of $\mathrm{CT}$, but the higher the measured returns in terms of any increase in wage. The benefits of CT for those who already have a high educational qualification seem to be related to rising wages to a much less extent than for those with a lower level of qualification. However, it is currently too early to conclude on the basis of these findings and on economic efficiency reasons that people with a lower educational qualification should receive more training because their returns to training are higher (this seems to be one conclusion of the OECD employment outlook report, OECD 1999). The positive VET impacts for low educated people found in cross sections (OECD 1999) might not stay constant in panel studies, hinting at unobserved heterogeneity problems in the cross-section studies (Abadie et al. 1999). 
A refined version of the hypothesis seems to be more in line with the evidence. To a certain extent, VET and CT can be substitutes. In those countries where individuals invest a comparably large amount in initial VET (for example workers in Germany), returns to $\mathrm{CT}$ are lower than in those countries where people invest a comparably smaller amount in initial training, for example workers in the United Kingdom (compare Blundell et al. 1999 and Pfeiffer and Reize 2000 or Pischke 1996) or in the United States, where returns to continuous training also seem to be rather high (Lynch 1994). The refined hypothesis therefore postulates that the returns to training after education are smaller if more people have received more initial education.

Fourth, government intervention in the training process of firms certainly has effects, which should be carefully investigated. There is some evidence that the French system provides more workers with training, because it is compulsory for firms to do so. However, in this system returns to training seem to be zero, even for those participating in training (Goux and Maurin 1998). Government interventions into private training processes might therefore have unintended negative secondary effects, which should be understood carefully for rational policy reasons.

Fifth, the returns to CT seem to be higher for employed workers than for the selfemployed (Pfeiffer and Reize 2000). From this result one can conclude that human capital aspects in the narrow sense of productivity enhancement only constitute one part of the training story. CT is the result of complex negotiations between workers and firms. Self-selection, firm selection, industrial relations, and internal promotion ladders are important factors in the process of training. Training often seems to be the result of a pre-selection process where workers are matched to hierarchical positions. It is not always training which leads to higher wages but rather the selection process which is the driving force behind an increase in wage. After selection for higher positions has taken place, workers are trained and receive higher wages. So, if we observe that a person has been trained, we often merely observe that he has been promoted. This is the case in the United Kingdom, Germany and other countries. However, in the United Kingdom returns to training seem to be higher than in Germany and investment in initial training is lower than in Germany. In France however, where firms have to provide training, returns equal zero. Therefore, training in the French system seems to be no indicator for internal promotion.

Sixth, in the papers reviewed there is no clear picture of market or government failure. While some findings can be interpreted as evidence of market failure ("poaching externalities", Hocquet 1999), others suggest that market forces work in the "right" direction. An example for the latter statement is that returns to employerprovided CT have turned out to be lower than those of indiv0idually provided CT which seems to be in line with forecasts from the human capital theory of G.S. Becker (Pannenberg 1997). Yet another example is the zero return result for France (Goux and Maurin 1998), which could be interpreted as government failure since it is compulsory for firms to provide training, whether it is efficient for them to do so, 
or not. But overall, the studies surveyed cannot be used to draw strong conclusions on the relevance of market or government failures.

Seventh, training in a competitive environment may have positive effects on some individuals and some firms, while it may have negative or positive effects on other individuals or firms at the same time, or later. Trained workers might crowd nontrained workers out of the labour force or out of jobs, and firms which provide more training and are more innovative might crowd other firms out of the product markets, because staff of the former are better motivated and they have innovative products. These negative, indirect effects cannot be ruled out in market economy. Good firms with superior technologies or lower costs have higher survival probabilities than other firms. However, if training is subsidised by government, assessment of VET programmes should take care of such indirect negative impacts. Some recent theoretical work is based on the assumption of positive external effects of VET (Acemoglu 1996, Lucas 1988). In the case of positive technological external effects, the productivity of trained workers in one firm is higher if the workers of other firms are also trained. Unfortunately, there is not yet enough empirical evidence on these issues with respect to training to be able to answer whether and under what circumstances training has a positive or negative secondary overall impact on society.

Eighth, there seems to be a large heterogeneity with respect to the determinants and effects of training. The estimated effects seem to differ between individuals, regions, over time and even between researchers and methods. This is true even if the same data are used, as can be seen by a comparison of the numerous studies performed by the British NCDS or the German GSOEP data. From the evidence surveyed in this paper and the diversity of it, it is therefore not possible to draw strong and very specific conclusions with respect to VET policies. However, it is possible to draw some broader conclusions with respect to VET-related policy and research issues, which is carried out in the next part.

\section{Conclusions}

Although there is widespread belief in a positive relationship between education, training and growth, the evidence provided so far is far from complete. Aggregate figures for the European Union suggest a clear hierarchical pattern in the labour market: those who are better educated are on average more frequently found in the work force, have higher earnings, participate more often in formal continuous training, are less often unemployed, are more often self-employed, have a higher regional mobility, and work with newer and more high tech equipment. Job mobility on the other hand is negatively correlated with the amount of human capital invested in a specific occupation, since investment increases switching costs. The pattern seems to have been rather stable over the past few decades, although continuing skill-biased technological change provides a challenge for VET policy in Europe. 
These stylised facts do not necessarily mean that those who are better educated or have higher educational qualifications also have a higher lifetime income or utility, because they often have higher costs in the investment period and there may be substantial comparative advantages for different educational pathways (for example, more cognitive or more mechanistic skills) for different people. Regarding heterogeneous individuals, there are individuals at the margin, whose lifetime utility is rather similar in different pathways, and there are individuals who receive higher utilities either with lower or higher educational qualifications.

What one would really like to know for policy analysis, is the value of the lifetime utility of a person for different educational pathways under different educational standards and regulations. However, these values are not observable and estimates available are far from being conclusive in all respects.

The critical review of more specific econometric work in this study indicates that training is indeed beneficial for both firms and individuals. The benefits are not negligible, in fact they are sometimes rather large. The fact that training has positive effects is however no guideline per se for government activity. There is evidence that self-selection on the one hand and general equilibrium effects on the other are at work. As a rule, training does have positive effects and net benefits for the trainees. However, there is some evidence that net effects for non-trainees might not be positive. In these cases training might be a bad investment for the respective people, firms and - from the viewpoint of economic efficiency - for society.

In addition, non negligible parts of observed differences in outcome variables such as earnings, wages, hours of work or career satisfaction cannot be attributed to education and training. Innate abilities, heterogeneity of abilities and preferences, family background, political events (for example the fall of the Berlin wall on the 9 November 1989 had significant impact on the East Germans), luck and the path of economic and technological development are all factors which are important. Selectivity, selection and general equilibrium effects also seem to play an important role in all training systems.

By and large, empirical results suggest that the more structured the whole training system is, and the more investment in general human capital is acquired while a person is young, the lower the returns to continuous training are after this high initial investment. If education is centralised and compulsory school attendance is expanded, then all people should achieve higher levels of education and formal skill levels. Selection into different career pathways transmitted through labour markets only begins after compulsory school attendance. If the level of more general types of skills learned in schools is high, training at the workplace plays a different role and is no longer responsible for building up these more general types of skills. Such mechanisms seem to be responsible for the lower returns to continuous training in countries such as Germany and France compared to the United Kingdom. Conversely, the less structured the training system is, the higher the measured returns of continuous training seem to be. 
European training systems differ. The different types of investment in VET, the spacing of these investments over an individual's life and the role of the state will depend on differences in prices for education, expected wage profiles, the skill structure of the workforce, tradition and technological factors. Success in schools and other training institutions is not the only factor explaining work-related success and careers. Labour market regulations and institutions might lead to insider power and create entry barriers and waiting queues for young workers, despite higher education and more investment in training. Such mechanisms seem to be present in most European countries, although to different degrees.

Some of the findings are a major challenge to the role of government in training. Obviously formal education and training are not omnipotent weapons against all storms of life for all people, but they may be very strong weapons when used at the right time, to the right extent and with the right content. At other times in an individual's working life, other weapons such as non-formal learning, regional, firm or occupational mobility might be more helpful.

Centralisation in the sense of generally acknowledged educational certificates (for example, trades in the German dual vocational training system) might be helpful for some occupations and especially when larger investments in educational qualifications are considered. However, there seem to be limits to such strategies.

First, the German apprenticeship system sometimes seems to react very slowly to rapid economic or technical change (Blechinger and Pfeiffer 2000) with the consequence that training curricula are old fashioned and skill obsolescence becomes a problem for firms and workers, which they try to overcome by additional and costly continuous training. Second, the set up and running costs of such a system can be rather high. More decentralised, deregulated and flexible systems such as those in the United Kingdom or the United States, which depend to a higher degree on market signals, might therefore have an advantage in times of rapid and unpredictable technical change. However, there may be other benefits of a more centralised system with compulsory school attendance. Youth unemployment is low in Germany and participation rates in VET is high. Imperfect capital markets, which can create entry barriers for poor young individuals in market economies, do not play a major role. No single optimal VET system exists. Policy makers have to put weight behind different policy objectives when policy changes are considered.

Key qualifications and more general human capital cannot be acquired in a short period of time. If technologies change, key qualifications will also change, at least to some extent. They have to be acquired through a long and continuing process (Weinert 1997) which presumably will have a sustainable impact when people are young or very young. The older individuals become, the more important non-formal and self-organised types of learning become. Mobility between occupations, regions and firms might also be valuable strategies for improving the career position of workers. 
For improving VET policies an adequate, systematic and regular research design ex ante would be helpful, allowing greater understanding of the relationship between specific VET activities carried out and its actual, secondary and desired results. Due to tight public budgets, evidence of impacts and efficiency of new and existing programmes will rise in the future. A research design that takes diversity of situations, heterogeneity of individuals, differences in training systems, governments, markets etc. is, however, expensive and takes time. If, for example, a unified European survey on VET were to be conducted in the year 2000, the results of the analysis would be available between 2001 and 2004 or even later. If one wished to compare the results over a longer horizon, for example, over a period of 30 years (see the NCDS data), results would not be available until 2030.

Besides research based on microdata which allows one to investigate the determinants and partial impacts of VET at individual level, general equilibrium effects should also be investigated using time series or panel data. Research on VET based on microdata might be improved if it would be more regularly and systematically based on Europe-wide conducted data sets, such as the ELFS, European Household Panel or the IALS. Despite remaining methodological problems, international surveys should have the advantage that the most interesting human capital and training variables are defined in comparable ways. Empirical results for different regions might be better comparable and differences in results might help to identify different impacts of national VET policies.

National VET programmes and policies dominate in Europe. It is therefore necessary to evaluate specific VET programmes on a regional or national basis. There is no need for standardised and Europe-wide evaluations if national VET programmes dominate. Most firms sometimes hold formal or more informal training programmes. There are, therefore, markets for training and these programmes seem to provide returns on investment which are as high as other investments in machines or research. However, the author is not aware of systematic research on the returns to training investment by private firms. This would be an additional source of extremely valuable knowledge and information for assessing public VET policies.

From the authors point of view, future research could be directed towards the following questions to improve understanding of the impacts of VET policies both on the individual and aggregate levels and optimise policy reactions to technology and other shocks. The questions are interrelated.

First: Research on specific public VET programmes should be intensified to learn about partial impacts at individual level and efficiency of programmes. This type of research will usually be based on microdata if the programmes are not too large. A partial evaluation design ignoring general equilibrium effects should suffice.

Second: Research on public VET systems should also be intensified. This type of research should evaluate the whole system and should take into account general equilibrium effects, financial efficiency and labour markets institutions as well. 
Research on this topic will usually be based on aggregate time series data, at individual panel data and official data on programme costs.

Third: Research on returns to VET for non-participants should be intensified. Should governments help non-participants and especially individuals with low skills to participate in VET or CT, or are other measures, for example wage subsidies, better for improving the labour market position of the low skilled?

Fourth: It is not fully understood, whether there are cumulative negative or positive relationships of public VET policies of different types transmitted through labour markets. Therefore research on the question of whether the public promotion of higher education in the last thirty years has had negative impacts on wages and labour market prospects of individuals with vocational education should be intensified to avoid the possibility of negative relationships in the future and improve coordination between educational and labour market policies.

Fifth: What is the efficiency of educational policies and the relative efficiency of higher and secondary education for the next 50 years for the cohort of young people entering the national training systems in the next five or 10 years? What is the optimal portfolio of different types of education, more general or more specific in nature for individuals, firms, regions or Europe? 


\section{List of references}

Abadie A., Angrist J., Imbens G. 1999. Instrumental variables estimates of the effects of subsidized training on the quantiles of trainee earnings. Paper presented at the ZEW Research Conference on Econometric Evaluations of Active Labour Market Policies in Europe, 25-26 June, 1999, Mannheim, Germany.

Acemoglu D., 1996. Credit constraints, investment externalities and growth. In: Booth A., Snower, D. J. eds., pp. 41-62.

Alba-Ramirez A., 1994. Formal Training, Temporary Contracts, Productivity and Wages in Spain. Oxford Bulletin of Economics and Statistics, 56 (2), pp. 151170 .

Andrews M., Bradley S., 1997. Modelling the Transition from School and the Demand for Training in the United Kingdom. Economica, 64, p. 387-413.

Arrow K. J., 1962. The Economic Implications of Learning by Doing, Review of Economic Studies, 29, 155-173.

Arulampalam W., Booth A. L., 1997. Who gets over the training hurdle? A study of the training experience of young men and women in Britain. Journal of Population Economics, 10, pp. 197-217.

Barnett A., O'Connell P. J., 1998. Does training generally work? The returns to incompany training. Discussion paper series No. 1879, Centre for Economic Policy Research, London.

Becker G. S., 1964. Human capital: a theoretical analysis with special references to education, New York: Columbia University Press.

Bellmann L., Bender S., Schank T., 1999. Flexibilität der Qualifikationsstruktur aus betrieblicher Sicht: Substitutionalität oder Komplementarität. Jahrbücher für Nationalökonomie und Statistik (Journal of Economics and Statistics), Vol.219, \#1+2, 109-126.

Blanchflower D., Lynch L., 1994. Training at work: a comparison of U.S. and British Youths. In: Lynch L., ed., pp. 233-260.

Blechinger D., Kleinknecht A., Licht G., Pfeiffer F., 1997. The Impact of Innovation on Employment in Europe - An Analysis Using CIS Data. EIMS Publication No. 46, European Commission.

Blechinger D., Pfeiffer F., 2000. Technological change and skill obsolescence: the case of German apprenticeship training. In: Heijke H., Muysken J., eds., Chapter 10.

Blundell R., Dearden L., Meghir C., 1997. The determinants and effects of work related training in Britain. The institute for fiscal studies, London.

Blundell R., Dearden L., Meghir C., 1999. Work-Related Training and Earnings. Prepared for the ZEW Research Conference on Econometric Evaluations of 
Active Labour Market Policies in Europe, 25-26 June, 1999, Mannheim, Germany.

BMBF, eds. 1999. Zur technologischen Leistungsfähigkeit Deutschlands. Zusammenfassender Endbericht 1998, Bundesministerium für Bildung und Forschung, Bonn.

Booth A. L., Snower D. J., 1996. Acquiring skills. Market failures, their symptoms and policy responses. New York: Cambridge University Press.

Bratberg E., Nilsen O.A. (1998). Transitions from school to work: search time and job duration, IZA Discussion Paper No. 27, Institute for the Study of Labor, Bonn.

Cohn E., Geske T. G., 1990. The economics of education. Oxford et al.: Pergamon Press ( $3^{\text {rd }}$ edition).

Dearden L., Ferri J., Meghir C., 1997. The effect of school quality on educational attainment and wages. The institute for fiscal studies, London.

Dolado J. J., Felgueroso F., Jimeno J. F., 1999. Youth labour markets in Spain: Education, Training, and Crowding out. Paper presented at the 1999 conference of the European Economic Association in Santiago de Compostela, Spain 2-4 September 1999.

Elias P., Hernaes E., Baker M, 1994. Vocational education and training in Britain and Norway. In: Lynch L., ed., pp. 283-298.

Entorf H., Kramarz F., 1997. Does unmeasured ability explain the higher wages of new technology workers? European Economic Review, 41, pp. 1489-1509.

EUROPEAN COMMISSION, 1997. Continuing vocational training: Europe, Japan and the United States of America. Official Publ. of the Europ. Communities, Luxembourg.

EUROSTAT, 1998. Erhebung über Arbeitskräfte. Ergebnisse 1997. Europäische Gemeinschaften, Luxembourg.

Franz W., Zimmermann V., 1999. Mobilität nach der beruflichen Erstausbildung: Eine empirische Studie für Westdeutschland (Job mobility after apprenticeship training in West Germany). Jahrbücher für Nationalökonomie und Statistik (Journal of Economics and Statistics), Vol. 219, \# 1+2, 143-164.

Gerlach K., Jirjahn U., 1998. Determinanten betrieblicher Weiterbildungsaktivitäten: Eine empirische Untersuchung mit Daten des Hannoveraner Firmenpanels. In: Pfeiffer F., Pohlmeier W., eds. pp. 311- 337.

Goux D., Maurin E., 1998. Returns to continuous training: evidence from French worker-firm matched data. Мimeo, Institut national de la statistique et des etudes economique, Paris.

Groot W., 1995. The Wage Effects of Investments in Enterprise-Related Training. Empirical Economics, 20, pp. 133-147. 
Groot W., Hartog J., Oosterbeek H., 1994. Returns to within-company schooling of employees: the case of the Netherlands. In: Lynch L., ed., pp. 299-308.

Hamermesh D. 1993. Labor demand. Princeton: Princeton University Press.

Hartog J. 2000. On returns to education: wandering along the hills of Oru Land. In: Heijke, H., Muysken J., eds., Chapter 2.

Heckman J. J., LaLonde R. J., Smith J., 1999. The economics and econometrics of active labour market programs. Paper presented at the ZEW Research Conference on Econometric Evaluations of Active Labour Market Policies in Europe, 25-26 June, 1999, Mannheim, Germany.

Heckman J. J., Lochner L., 1998. Explaining rising wage inequality: explorations with a dynamic general equilibrium model of labor earnings with heterogeneous agents. Review of Economic Dynamics, Vol. 1, pp. 1-58.

Heckman J. J., Lochner L., Taber C., 1999. General-Equilibrium Cost-Benefit Analysis of Education and Tax Policies. In: Ranis, G, Raut, L.K. (eds.), Trade, Growth and Development. Amsterdam: Elsevier Science, Chapter 14.

Heckman J. J., Smith J. A., 1998. Evaluating the Welfare State. In: Strom, S. (ed.), Econometrics and Economic Theory in the $20^{\text {th }}$ Century, Cambridge: Cambridge University Press, Chapter 8.

Heijke H., Muysken J., eds., 2000. Education, Training and Employment in the Knowledge Based Economy. London: AEA-Macmillan Series.

Hocquet L., 2000. Vocational training and the poaching externality: evidence from France. In: Heijke, H., Muysken J., eds., Chapter 9.

Jonker N., de Crip A., van Smoorenburg M. 1997. Do employees with flexible contracts participate less in training? Paper presented at the LVIIth International Conference of the Applied Econometrics Association, May 14-16, Maastricht.

Krueger A., Rouse C., 1994. New Evidence on Workplace Education. NBER Working Paper, \#4831.

Levhari D., Weiss Y., 1974. The Effect of Risk on the Investment in Human Capital. American Economic Review, 64 (6), pp. 950-963.

Lucas R.E., 1988. On the Mechanics of Economic Development. Journal of Monetary Economics, Vol. 22, 3-42.

Lynch L. ed., 1994. Training and the Private Sector. International Comparisons. Chicago, London: The University of Chicago Press.

Machin S., 1996. Changes in the relative demand for skills. In: Booth A., Snower, D. J. eds., pp. 127-176.

Machin S., van Reenen J., 1998. Technology and changes in skill structure: evidence from seven OECD countries. The Quarterly Journal of Economics CXIII, pp. 1215-1244. 
Mayer K. U., 1996. Ausbildungswege und Berufskarrieren. In: Bundesinstitut für Berufsbildung eds., Forschung im Dienst von Praxis und Politik. Bielefeld: W.Bertelsmann Verlag, pp. 113-145.

Mayer, K. U., Carroll G., 1987. Jobs and Classes: structural constraints on career mobility. European Sociological Review, 3 (1) pp. 14-38.

Müller W., Shavit Y., 1998. The institutional embeddedness of the stratification process: A comparative study of qualifications and occupations in thirteen countries. In: Müller W., Shavit Y., eds., pp. 1-48.

Müller W., Shavit Y., eds., 1998. From school to work. A comparative study of educational qualifications and occupational destinations. Oxford: Clarendon Press, pp.1-48.

OECD, 1998a. Education at glance. OECD indicators. OECD-Publications, Paris.

OECD, 1998b. Pathways and participation in vocational and technical education and training. OECD-Publications, Paris.

OECD, 1999. OECD Employment Outlook. OECD-Publications, Paris.

Oosterbeek H., 1998. Unravelling supply and demand factors in work - related training, Oxford Economic Papers. New Series, 50, 266-283.

Pannenberg M., 1995. Weiterbildungaktivitäten und Erwerbsbiographie. Eine empirische Analyse für Deutschland. Frankfurt, New York: Campus.

Pannenberg M., 1997. Financing on-the-job-training: shared investment or promotion based systems? Evidence from Germany. Zeitschrift für Wirtschaftsund Sozialwissenschaften, 117 (4), pp.525-543.

Pannenberg M., 1998. Weiterbildung, Betriebszugehörigkeit und Löhne: Ökonomische Effekte des "timings" von Investitionen in die berufliche Weiterbildung. In: Pfeiffer F., Pohlmeier W., eds., pp. 257-278.

Pfeiffer F., 1997. Humankapitalbildung im Lebenszyklus. In: Clar G., Dorè J., Mohr H., eds., Humankapital und Wissen - Grundlagen einer nachhaltigen Entwicklung, Springer: Berlin, Heidelberg, pp. 173-195.

Pfeiffer F., Brade J., 1995. Weiterbildung, Arbeitszeit und Lohneinkommen. In: Steiner, V., Bellmann L., eds. Mikroökonomik des Arbeitsmarktes, Beiträge zur Arbeitsmarkt- und Berufsforschung, Nürnberg, 192, pp. 289-326.

Pfeiffer F., Falk M., 1999. Der Faktor Humankapital in der Volkswirtschaft Berufliche Spezialisierung und technologische Leistungsfähigkeit. Nomos: Baden-Baden.

Pfeiffer F., Pohlmeier W., eds. 1998. Qualifikation, Weiterbildung und Arbeitsmarkterfolg, Nomos: Baden-Baden.

Pfeiffer F., Reize F., 2000. Formelle und informelle berufliche Weiterbildung und Verdienst bei Arbeitnehmern und Selbständigen. In: Weizsäcker R.K.v., ed. Bildung und Beschäftigung: Duncker \& Humblot: Berlin (to appear soon). 
Pischke J.S., 1996. Continuous training in Germany. NBER-working paper, No 5829, Chicago.

Prendergast C. J., 1993. The role of promotion inducing specific human capital acquisition. Quarterly Journal of Economics, 108, pp. 523-534.

Schömann K., Becker R., 1995. Participation in further education over the life course. European Sociological Review, 11, pp. 187-208.

Schröder L., Blomskog S., 1997. Labour market entry, vocational training and mobility in the Swedish young work force 1950-1991. Paper presented at the LVII $^{\text {th }}$ International Conference of the AEA, May 14-16, Maastricht.

Snower D. J., 1996. The low-skill, bad-job trap. In: Booth A., Snower, D. J. eds., pp. 109-126.

Tessaring M., 1999. Training for a changing society - A report on current vocational education and training research in Europe 1998. $2^{\text {nd }}$ ed. CEDEFOP, Luxembourg: EUR-OP.

Weinert F. E. (1997). Grenzen der Entwicklung des Humankapitals aus der Sicht der psychologischen Lerntheorie. In: Clar G., Dorè J., Mohr H., eds., Humankapital und Wissen - Grundlagen einer nachhaltigen Entwicklung, Springer: Berlin, Heidelberg, pp. 137-156.

Weinert F. E., Schneider W. eds. (1998). Individual development from 3 to 12: Findings from the Munich Longitudinal Study, Cambridge University Press: New York.

Weiss A., 1994. Productivity changes without formal training. In: Lynch L., ed., pp. 149-160.

Weiss A., 1995. Human capital vs. signalling explanation of wages. Journal of Economic Perspectives, 9 (4), pp. 133-154.

Wolpin K., 1977. Education and screening. The American Economic Review. 67 (5), pp.949-958. 


\section{Annex}

Table 1: Education and economic performance - some indicators

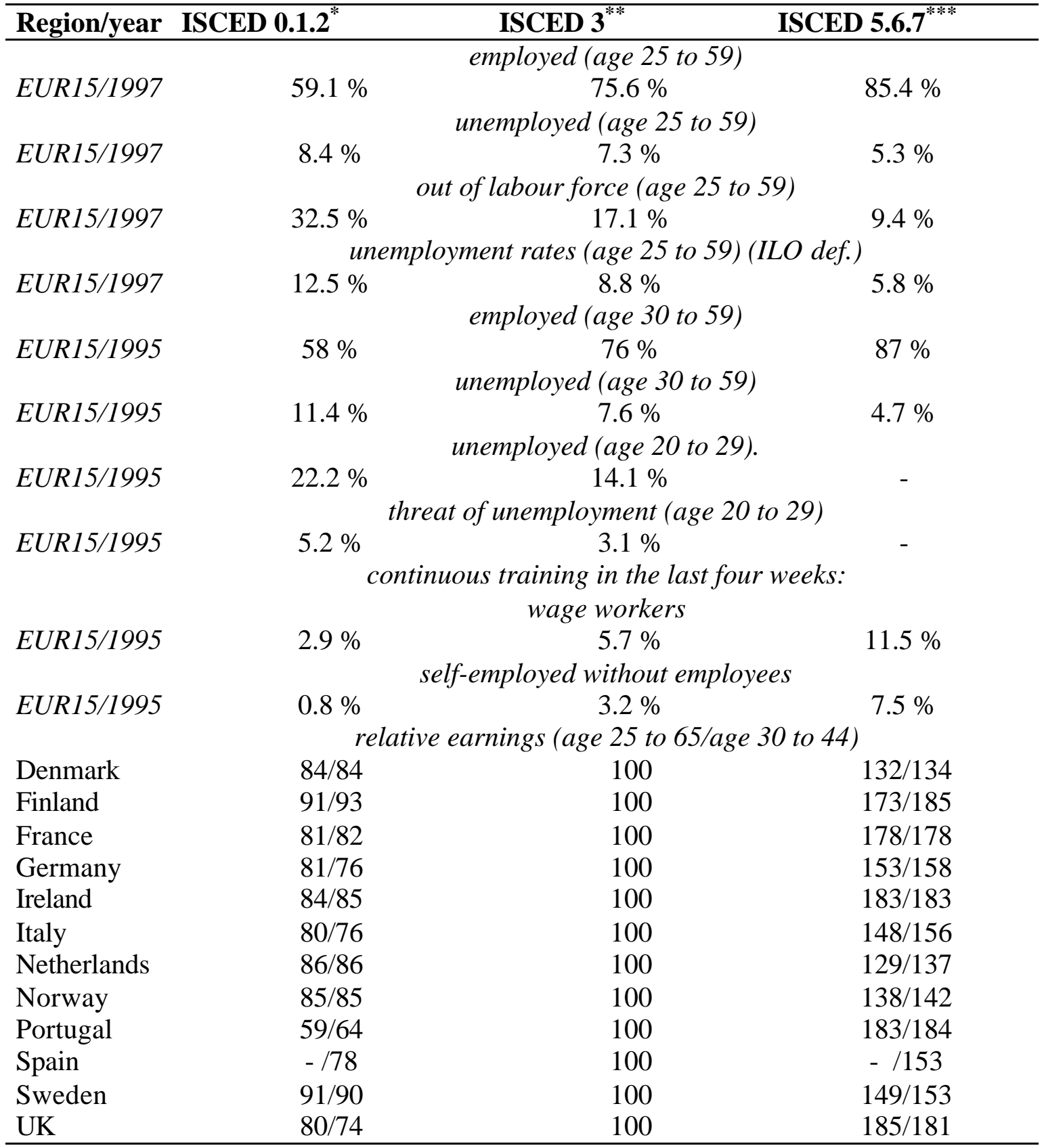

*ISCED Level 0: Pre-primary education, 1: Primary education, 2: Lower secondary second **ISCED Level 3: Higher Secondary education ***ISCED Level 5,6,7: Higher Education

Sources: own composition from EUROSTAT (1998), European Commission (1997), OECD (1998a). 
Table 2: Individual and firm data

\begin{tabular}{|c|c|c|c|c|c|c|c|c|}
\hline $\begin{array}{l}\text { Description } \\
\text { (abbreviation in } \\
\text { brackets) }\end{array}$ & $\begin{array}{l}\text { Country/ } \\
\text { Region }\end{array}$ & $\begin{array}{l}\text { Type } \\
*\end{array}$ & $\underset{* *}{\operatorname{Aims}}$ & $\begin{array}{l}\text { Unit of } \\
\text { observation }\end{array}$ & Sample & Start & $\begin{array}{l}\text { Frequency of } \\
\text { interviews }\end{array}$ & $\begin{array}{l}\text { Years under } \\
\text { investigation }\end{array}$ \\
\hline Brabant Survey (BRAS) & Netherlands & $\mathrm{CD}$ & $\mathrm{B}$ & individual & Cohort 6. Class 1952 & 1952 & $1952 / 1983$ & 1983 \\
\hline $\begin{array}{l}\text { Lancashire Career Service } \\
\text { Data (LCSD) }\end{array}$ & $\begin{array}{l}\text { United } \\
\text { Kingdom }\end{array}$ & $\mathrm{CD}$ & A & individual & Cohort of school leavers & 1991 & 1 year & 1991 \\
\hline $\begin{array}{l}\text { Dutch wave of the } \\
\text { International Adult } \\
\text { Literary Survey (DIALS) }\end{array}$ & Netherlands & CS & B & individual & Representative for the population & 1995 & once & 1995 \\
\hline $\begin{array}{l}\text { Dutch biannual labour } \\
\text { supply survey (OSA) }\end{array}$ & Netherlands & PD & B & individual & Wage workers 1994 & 1992 & biannually & 1994 \\
\hline $\begin{array}{l}\text { French Survey on } \\
\text { Education and } \\
\text { Qualifications (FQP) }\end{array}$ & France & CS & A & $\begin{array}{l}\text { individuals } \\
\text { (matched } \\
\text { with firm } \\
\text { data) }\end{array}$ & $\begin{array}{l}\text { Representative sample of French } \\
\text { adult population }\end{array}$ & 1993 & $?$ & 1993 \\
\hline $\begin{array}{l}\text { German Labour Force } \\
\text { Survey (GLFS) }\end{array}$ & $\begin{array}{l}\text { Germany } \\
\text { (before } 1989 \\
\text { West Ger.) }\end{array}$ & RCS & B & individual & $\begin{array}{l}\text { Representative sample of the } \\
\text { population }\end{array}$ & 1981 & 1 year & 1991, 1993, 1995 \\
\hline $\begin{array}{l}\text { German life history study } \\
\text { (GLHS) }\end{array}$ & $\begin{array}{l}\text { Germany } \\
\text { (before } 1989 \\
\text { West Ger.) }\end{array}$ & $\mathrm{CD}$ & A & individual & Representative sample of cohorts & $\begin{array}{l}1929- \\
1931\end{array}$ & $\begin{array}{l}1929-1931, \\
1949-1951, \\
1954-1956, \\
1959-1968\end{array}$ & all \\
\hline $\begin{array}{l}\text { German Socio-Economic } \\
\text { Panel (GSOEP) }\end{array}$ & $\begin{array}{l}\text { Germany } \\
\text { (before } 1989 \\
\text { West Ger.) }\end{array}$ & PD & B & individuals & $\begin{array}{l}\text { Representative sample of the } \\
\text { population }\end{array}$ & 1984 & 1 year & 1986-1993 \\
\hline $\begin{array}{l}\text { Social Insurance Data } \\
\text { (KIRUT) }\end{array}$ & Norway & $\mathrm{PD}$ & $\mathrm{C}$ & individuals & $\begin{array}{l}10 \% \text { sample of the Norwegian } \\
\text { population }\end{array}$ & 1989 & regularly & 1989-1994 \\
\hline
\end{tabular}




\begin{tabular}{|c|c|c|c|c|c|c|c|c|}
\hline $\begin{array}{l}\text { Description } \\
\text { (abbreviation in } \\
\text { brackets) }\end{array}$ & $\begin{array}{l}\text { Country/ } \\
\text { Region }\end{array}$ & $\begin{array}{l}\text { Type } \\
*\end{array}$ & $\underset{* *}{\operatorname{Aims}}$ & $\begin{array}{l}\text { Unit of } \\
\text { observation }\end{array}$ & Sample & Start & $\begin{array}{l}\text { Frequency of } \\
\text { interviews }\end{array}$ & $\begin{array}{l}\text { Years under } \\
\text { investigation }\end{array}$ \\
\hline $\begin{array}{l}\text { National Child } \\
\text { Development Study } \\
\text { (NCDS) }\end{array}$ & Great Britain & $\mathrm{CD}$ & B & individual & Cohort of people born in 1958 & 1958 & $\begin{array}{l}1958 / 1965 / \\
1974 \\
1981 / 1991\end{array}$ & $\begin{array}{l}1974 \text { to } 1981 \\
\text { and } 1981 \text { to } \\
1991\end{array}$ \\
\hline Norway Survey (NORS) & Norway & $\mathrm{CD}$ & $\mathrm{B}$ & individual & $\begin{array}{l}\text { Cohort of people born from } 1956 \\
\text { to } 1958\end{array}$ & 1975 & $1975 / 1981$ & 1975 to 1981 \\
\hline $\begin{array}{l}\text { Qualification and Career } \\
(\mathbf{Q} \& \mathbf{C})\end{array}$ & Germany & RCS & $\mathrm{A}$ & individual & $\begin{array}{l}\text { Representative sample of } \\
\text { employees }\end{array}$ & 1979 & $\begin{array}{l}1979 / 1985 / \\
1991\end{array}$ & 1979 to 1991 \\
\hline $\begin{array}{l}\text { Swedish Level of Living } \\
\text { Surveys (SLLS) }\end{array}$ & Sweden & RCS & B & individuals & $\begin{array}{l}\text { Representative sample of } \\
\text { Swedish population }\end{array}$ & 1968 & $\begin{array}{l}1968 / 1974 / \\
1981 \\
1991\end{array}$ & 1968 to 1991 \\
\hline $\begin{array}{l}\text { Community Innovation } \\
\text { Survey (CIS) }\end{array}$ & Europe & CS & $\mathrm{C}$ & firms & Firms from the industrial sector & 1993 & once & 1993 \\
\hline $\begin{array}{l}\text { Collective Bargaining in } \\
\text { Large Firms (NCGE) }\end{array}$ & Spain & PD & $\mathrm{C}$ & firms & $\begin{array}{l}\text { Representative sample of firms } \\
\text { with more than } 200 \text { employees }\end{array}$ & 1979 & 1 year & $1988 / 1989$ \\
\hline $\begin{array}{l}\text { Company training in } \\
\text { Ireland (CTIRE) }\end{array}$ & Ireland & CS & A & firms & $\begin{array}{l}\text { Representative sample of firms } \\
\text { from Ireland }\end{array}$ & 1993 & once & 1993 \\
\hline German Plant Panel (GPP) & Germany & PD & $\mathrm{C}$ & $\begin{array}{l}\text { plants of } \\
\text { firms }\end{array}$ & $\begin{array}{l}\text { Representative sample of plants } \\
\text { matched with personal data }\end{array}$ & 1993 & 1 year & 1995 \\
\hline $\begin{array}{l}\text { Hanover Firm Panel } \\
\text { (HFP) }\end{array}$ & $\begin{array}{l}\text { Lower- } \\
\text { Saxony; } \\
\text { Germany }\end{array}$ & PD & $\mathrm{C}$ & firms & $\begin{array}{l}\text { Representative sample of firms } \\
\text { from the industrial sector }\end{array}$ & 1993 & 1 year & 1993 to 1995 \\
\hline
\end{tabular}

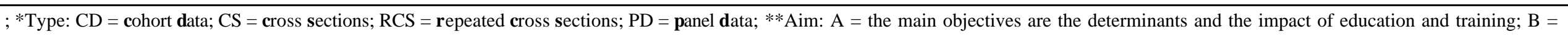
the main objectives are related to education and training; $\mathrm{C}=$ the main objectives focus on other topics, but meaningful questions on education and training are included.

Source: own composition 
Table 3: Dimensions of training in micro-econometric studies

\begin{tabular}{|c|c|}
\hline Dimension & Description \\
\hline Type of training & initial training, continuous training; \\
\hline \multirow[t]{2}{*}{ Degree of formality } & $\begin{array}{l}\text { informal training (learning by doing); } \\
\text { formal training courses: }\end{array}$ \\
\hline & $\begin{array}{l}\text { without a recognised vocational qualification, } \\
\text { with a recognised vocational qualification. }\end{array}$ \\
\hline \multirow[t]{3}{*}{ Content } & general knowledge; \\
\hline & work-related training courses; \\
\hline & occupation-specific training courses. \\
\hline \multirow[t]{2}{*}{ Subject } & electronic data processing, \\
\hline & languages etc. \\
\hline \multirow[t]{3}{*}{ Provider } & employer-provided training courses; \\
\hline & individually provided training courses; \\
\hline & government-provided training courses \\
\hline \multirow[t]{3}{*}{ Place } & at the school; in the classroom; \\
\hline & at the workplace, inside a firm; \\
\hline & outside the firm \\
\hline Duration & in days, month or years \\
\hline Frequency & number of courses taken in a month, year or in a 10 year period \\
\hline $\begin{array}{l}\text { Amount of resources } \\
\text { invested }\end{array}$ & costs \\
\hline
\end{tabular}

Source: own composition 
Table 4: The outcome of training

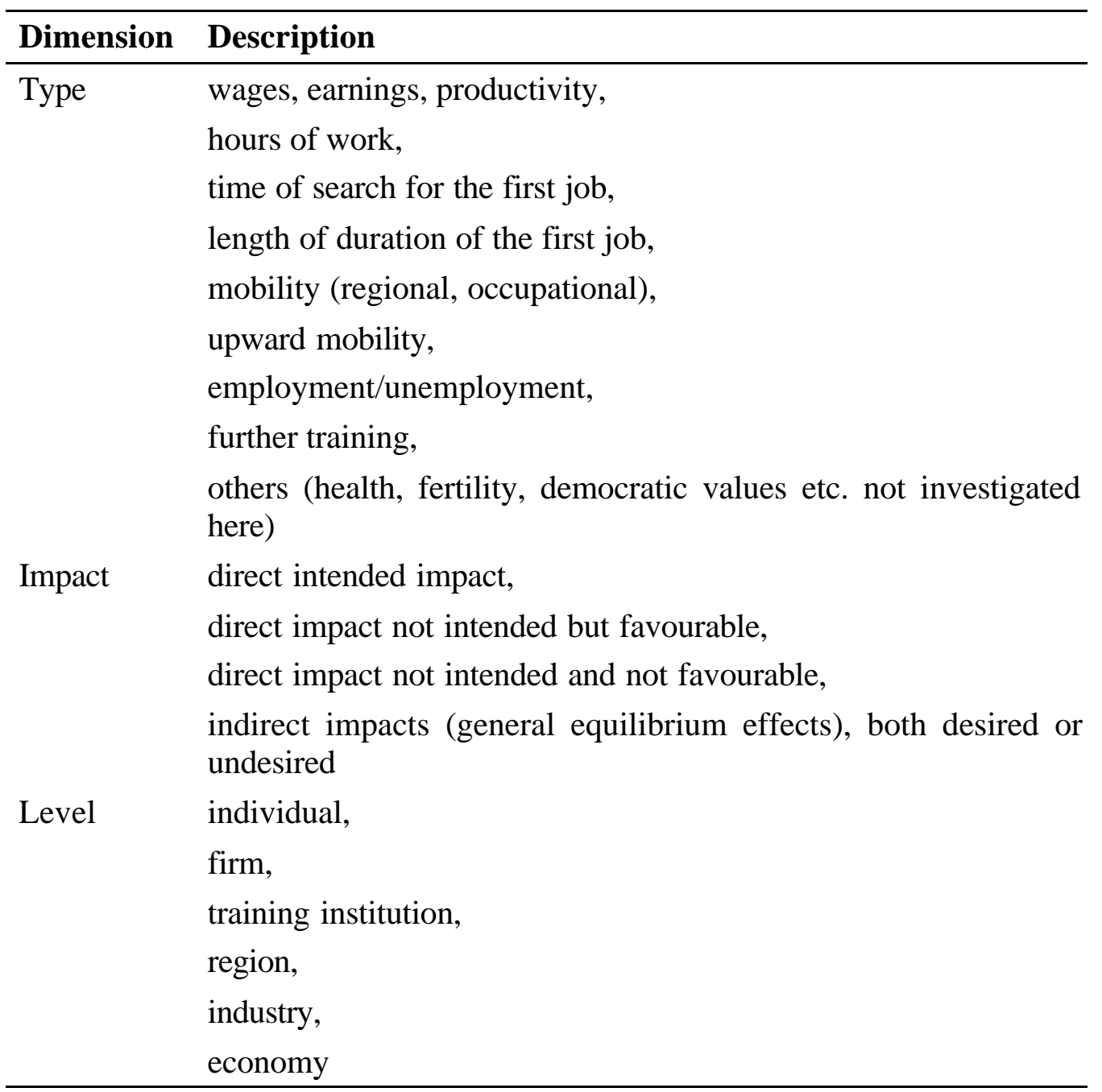

Source: own composition 
Table 5: Determinants of the participation in VET/CT: summary

\begin{tabular}{|c|c|c|c|c|c|}
\hline Data & Study & Type & Sample & $\begin{array}{l}\text { Educational } \\
\text { background, } \\
\text { ability }\end{array}$ & Econometric method \\
\hline$N C G E$ & $\begin{array}{l}\text { Alba-Ramirez } \\
\text { (1994) }\end{array}$ & $\begin{array}{l}\text { Firm-based training } \\
\text { Firm-based training for } \\
\text { junior, } \\
\text { senior employees }\end{array}$ & $\begin{array}{l}\text { Firms with more than } \\
200 \text { employees }\end{array}$ & $\begin{array}{l}+ \\
0 \\
+\end{array}$ & Probit, tobit model \\
\hline$L C S$ & $\begin{array}{l}\text { Andrews/Bradley } \\
\text { (1997) }\end{array}$ & $\begin{array}{l}\text { Vocational training or } \\
\text { Non-vocational training }\end{array}$ & $\begin{array}{l}\text { Young people leaving } \\
\text { compulsory school } \\
\text { Women } \\
\text { Men }\end{array}$ & $\begin{array}{l}\text { - (academic ability) } \\
\text { - (exam performance) }\end{array}$ & multinomial logit \\
\hline$N C D S$ & $\begin{array}{l}\text { Arulampalam/ } \\
\text { Booth (1997) }\end{array}$ & $\begin{array}{l}\text { Determinants job-related } \\
\text { training }\end{array}$ & Men & $\begin{array}{l}+ \text { (qualification) } \\
-(\text { reading score }) \\
+(\text { math score }) \\
0 \text { (reading and math } \\
\text { score) }\end{array}$ & Negbin hurdle model \\
\hline & & Number of courses & Men & $\begin{array}{l}0 \text { (qualification) } \\
0 \text { (ability) } \\
+ \text { (qualification) } \\
0 \text { (ability) }\end{array}$ & \\
\hline
\end{tabular}


Table 5 continue

\begin{tabular}{|c|c|c|c|c|c|c|}
\hline Data & Study & Type & Sample & $\begin{array}{l}\text { Educational } \\
\text { background, } \\
\text { ability }\end{array}$ & Experience & Econometric method \\
\hline \multirow[t]{2}{*}{$N C D S$} & $\begin{array}{l}\text { Blundell, } \\
\text { Dearden, Meghir } \\
(1997,1999)\end{array}$ & $\begin{array}{l}\text { Work-related training with } \\
\text { a recognised vocational } \\
\text { qualification }\end{array}$ & $\begin{array}{l}\text { Men } \\
\text { Women }\end{array}$ & $\begin{array}{l}+ \\
+\end{array}$ & & Probit, ordered probit \\
\hline & & Employer provided training & $\begin{array}{l}\text { Men } \\
\text { Women }\end{array}$ & $\begin{array}{l}+ \\
+\end{array}$ & & probit, ordered probit \\
\hline HFP & $\begin{array}{l}\text { Gerlach/Jirjahn } \\
\text { (1998) }\end{array}$ & Firm financed CT & Industrial enterprises & $\begin{array}{l}\text { share of academic } \\
\text { workforce }+ \\
\text { share of blue-collar } \\
\text { workers - }\end{array}$ & & $\begin{array}{l}\text { Random Effects probit } \\
\text { model; ordered probit }\end{array}$ \\
\hline$F Q P$ & $\begin{array}{l}\text { Goux/Maurin } \\
\text { (1998) }\end{array}$ & $\begin{array}{l}\text { Employer sponsored } \\
\text { training }\end{array}$ & $\begin{array}{l}\text { Workers in the private } \\
\text { sector }\end{array}$ & + & + & $\begin{array}{l}\text { Bivariate probit (mobility } \\
\text { and training) }\end{array}$ \\
\hline$B R A S$ & $\begin{array}{l}\text { Groot }(1995), \\
\text { Groot/Hartog/ } \\
\text { Oosterbeek } \\
(1994)\end{array}$ & Enterprise-related training & Wage earners & $\begin{array}{l}+ \text { (ability) } \\
\text { (education not } \\
\text { significant) }\end{array}$ & + & MLE \\
\hline$O S A$ & $\begin{array}{l}\text { Jonker/de } \\
\text { Crip/van } \\
\text { Smoorenburg } \\
(1997)\end{array}$ & CT with the employer & Employed workers & 0 & & Probit \\
\hline GSOEP & $\begin{array}{l}\text { Pannenberg } \\
(1995,1997, \\
1998)\end{array}$ & $\begin{array}{l}\text { CT (duration, number, } \\
\text { place, financing) }\end{array}$ & $\begin{array}{l}\text { Full or part-time } \\
\text { employed workers }\end{array}$ & + & $\begin{array}{l}\text { inverted u- } \\
\text { shape }\end{array}$ & $\begin{array}{l}\text { Ordered probit, negbin } \\
\text { hurdle model, } \\
\text { multinomial logit }\end{array}$ \\
\hline
\end{tabular}


Table 5 continue

\begin{tabular}{|c|c|c|c|c|c|c|}
\hline Data & Study & Type & Sample & $\begin{array}{l}\text { Educational } \\
\text { background, } \\
\text { ability }\end{array}$ & Experience & Econometric method \\
\hline$Q \& C$ & $\begin{array}{l}\text { Pfeiffer/Reize } \\
\text { (1999) }\end{array}$ & $\mathrm{CT}$ & $\begin{array}{l}\text { Employed worker } \\
\text { Self-employed }\end{array}$ & $\begin{array}{l}+ \\
0\end{array}$ & $\begin{array}{l}\text { inverted } u- \\
\text { shape } \\
0\end{array}$ & $\begin{array}{l}\text { Probit, ordered probit, } \\
\text { MLE }\end{array}$ \\
\hline DIALS & $\begin{array}{l}\text { Oosterbeek } \\
\text { (1998) }\end{array}$ & $\begin{array}{l}\text { CT (work-related) in the } \\
\text { last } 12 \text { month }\end{array}$ & Employed people & $\begin{array}{l}\text { + (numerical skills) } \\
\text { Qualification: } \\
\text { individuals do care, } \\
\text { firms do not }\end{array}$ & $\begin{array}{l}\text { inverted u- } \\
\text { shaped }\end{array}$ & Probit, bivariate probit \\
\hline GLHS & $\begin{array}{l}\text { Schömann/Becker } \\
\text { (1995) }\end{array}$ & $\mathrm{CT}$ & $\begin{array}{l}\text { Males } \\
\text { Females }\end{array}$ & $\begin{array}{l}+ \\
+\end{array}$ & $\begin{array}{l}\text { cohort } \\
\text { effects }\end{array}$ & Partial likelihood \\
\hline
\end{tabular}

Source: own composition 
Table 6: The effects of VET: summary

\begin{tabular}{|c|c|c|c|c|c|c|}
\hline Data & Study & Training & sample & wage/earnings & $\begin{array}{l}\text { post training } \\
\text { mobility }\end{array}$ & employment \\
\hline NCGE & Alba-Ramirez (1994) & Firm-provided training & $\begin{array}{l}\text { Industry enterprises } \\
\text { with more than } 200 \\
\text { employees }\end{array}$ & $\begin{array}{l}\text { Labour productivity }+28 \% \\
\text { (4.2) (mainly driven by } \\
\text { training of senior } \\
\text { employees) }\end{array}$ & & \\
\hline CTIRE & $\begin{array}{l}\text { Barnett/O'Connell } \\
\text { (1998) }\end{array}$ & $\begin{array}{l}\text { General training } \\
\text { Specific training } \\
\text { (Training Expenditure Total payroll) }\end{array}$ & Private enterprises & $\begin{array}{l}+2.0(1.9) \\
-0.8(-1.0)\end{array}$ & & \\
\hline$N C D S$ & $\begin{array}{l}\text { Blanchflower/Lynch } \\
\text { (1994) }\end{array}$ & $\begin{array}{l}\text { Training with current firm } \\
\text { Apprenticeship } \\
\text { No qualification } \\
\text { + City \& Guild Craft } \\
\text { + City \& Guild Awards } \\
\text { Training with current firm } \\
\text { Apprenticeship } \\
\text { No qualification } \\
\text { + City \& Guild Craft } \\
\text { + City \& Guild Awards }\end{array}$ & Women & $\begin{array}{l}1.8(1.5) \\
1.8(2.3) \\
1.9(0.1) \\
7.2(3.3) \\
2.6(2.3) \\
1.8(1.7) \\
1.6(0.03) \\
2.7(0.3)\end{array}$ & & \\
\hline$N C D S$ & $\begin{array}{l}\text { Blundell, Dearden, } \\
\text { Meghir (1997) }\end{array}$ & $\begin{array}{l}\text { Employer provided } \\
\text { training current job } \\
\text { On-the-job } \\
\text { Off-the-job } \\
\text { Previous job } \\
\text { On-the-job } \\
\text { Off-the-job } \\
\text { Other work-related training } \\
\text { Employer provided } \\
\text { training current job } \\
\text { On-the-job } \\
\text { Off-the-job }\end{array}$ & Women & $\begin{array}{l}+4.1(1.7) \\
+7.2(3.0) \\
+6.2(1.67) \\
+6.0(2.1) \\
6.7(3.2) \\
+0.3(0.1) \\
+4.6(1.4)\end{array}$ & & + \\
\hline
\end{tabular}


Table 6 continue

\begin{tabular}{|c|c|c|c|c|c|c|}
\hline Data & Study & Training & sample & wage/earnings & $\begin{array}{l}\text { post training } \\
\text { mobility }\end{array}$ & employment \\
\hline & & $\begin{array}{l}\text { Previous job } \\
\text { On-the-job } \\
\text { Off-the-job } \\
\text { Other work related training }\end{array}$ & & $\begin{array}{l}+0.5(0.1) \\
1.0(0.3) \\
+6.6(2.4)\end{array}$ & & \\
\hline KIRUT & Bratberg/Nilsen (1998) & $\begin{array}{l}<10,10-12,13-15,>15 \text { years in } \\
\text { education }\end{array}$ & Men / Women & increasing with education & $\begin{array}{l}\text { Increasing with } \\
\text { education }\end{array}$ & $\begin{array}{l}+(13-15 \\
\text { years })\end{array}$ \\
\hline NORS & $\begin{array}{l}\text { Elias/Hernaes/Baker } \\
\text { (1994) }\end{array}$ & $\begin{array}{l}\text { Vocational apprenticeship formal } \\
\text { certificate }\end{array}$ & $\begin{array}{l}\text { Men age } 22-24 \\
\text { Women age } 22-24\end{array}$ & $\begin{array}{l}-/ 0 \\
-/ 0 \\
\end{array}$ & & \\
\hline$F Q D$ & Goux/Maurin (1998) & Firm-provided training & Wage earners & $\begin{array}{l}+7 \%(3.5) \\
\text { Selectivity bias corrected: } \\
-5.7(0.9)\end{array}$ & $\begin{array}{l}0 \\
\text { (firm mobility) }\end{array}$ & \\
\hline$\overline{B R A S}$ & Groot (1995) & Enterprise-related training & $\begin{array}{l}\text { Wage earners } \\
\text { Trained } \\
\text { Not trained }\end{array}$ & $\begin{array}{l}\text { Rate of return per year } \\
\text { Average marginal } \\
+28 \% \quad-0.16 \\
-83 \% \quad-0.16 \\
\end{array}$ & & \\
\hline$F Q D$ & Hocquet (1999) & $\begin{array}{l}\text { Employer-provided training } \\
\text { Content (11 categories) } \\
\text { Qualification (6 categories) } \\
\text { Duration ( } 11 \text { categories) } \\
\text { From current firm } \\
\text { From previous firm } \\
\end{array}$ & Wage earners, men & $\begin{array}{l}0-28 \% \\
0-17 \% \\
5-11 \% \text { (not ordered) } \\
+7 \% \\
+10 \%-+18 \%\end{array}$ & & \\
\hline GLHS & $\begin{array}{l}\text { Mayer (1996) } \\
\text { Mayer/Caroll(1987) }\end{array}$ & $\begin{array}{l}\text { Vocational apprenticeship compared } \\
\text { to no vocational training }\end{array}$ & Employed & & $\begin{array}{l}+ \text { (expert } \\
\text { statement) }\end{array}$ & $\begin{array}{l}+ \text { (qualitative } \\
\text { statement) }\end{array}$ \\
\hline$\overline{G S O E P}$ & Pannenberg $(1995,1997)$ & $\begin{array}{l}\text { CT } \\
\text { on-the-job training } \\
\text { employer-financed }\end{array}$ & Wage earners & $\begin{array}{l}+9 \%(2.9) \\
+3 \%(0.9)\end{array}$ & $\begin{array}{l}\text { Change of } \\
\text { employer: } 0 \\
\text { upward mobility } \\
+ \text { (short courses) }\end{array}$ & \\
\hline
\end{tabular}


Table 6 continue

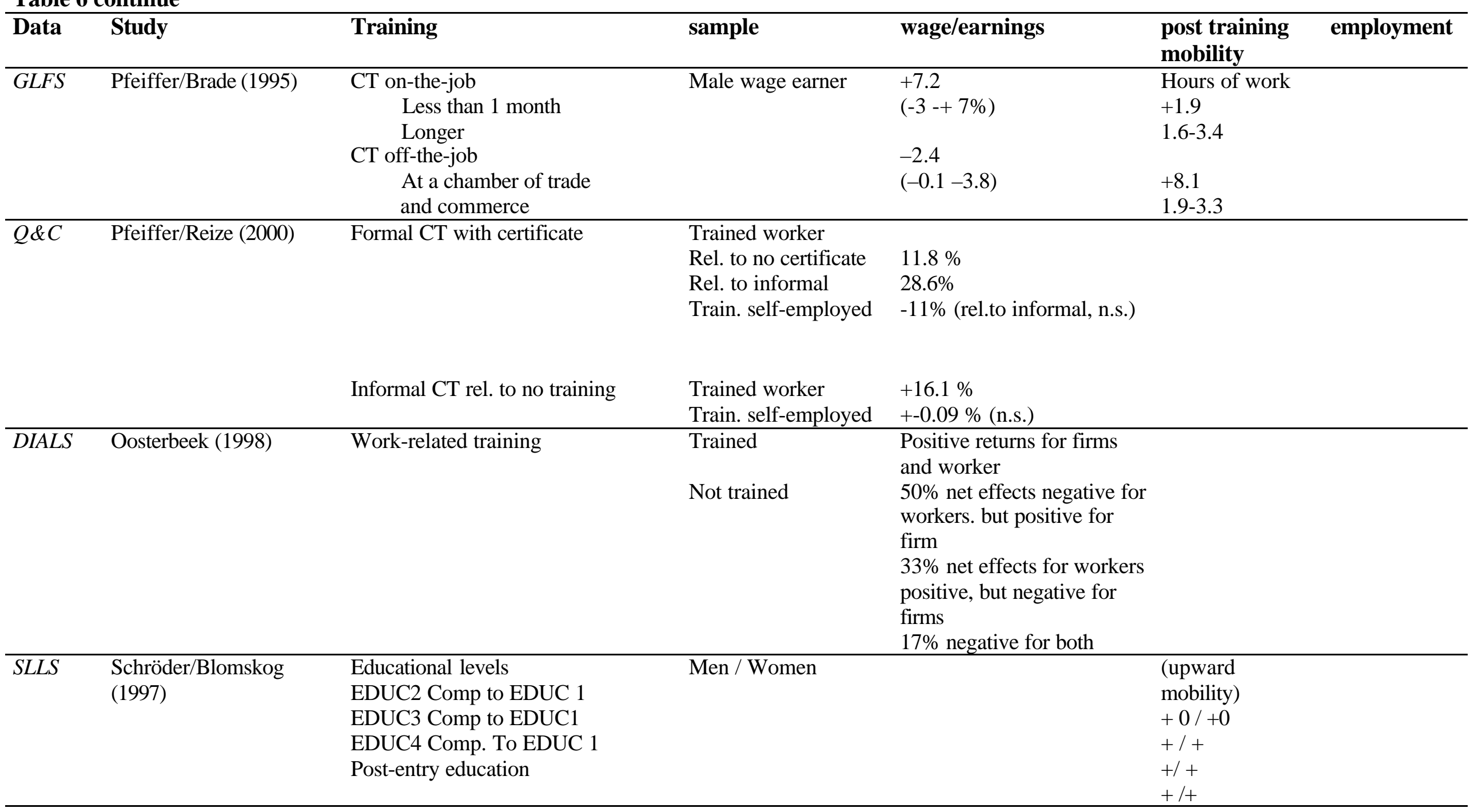

Source: own composition 